\title{
Matematik Öğretmeni Adaylarının Ölçme ve Değerlendirme Bilgi Gelişimleri
}

\section{Examining Development of Assessment Knowledge of Prospective Mathematics Teachers}

\section{Ömer ŞAHIN ${ }^{* *}($ DD}

\author{
Yasin SOYLU ${ }^{* * *}$ (D)
}

\begin{abstract}
Received: 18 August 2017
Research Article

Accepted: 02 December 2018

ABSTRACT: The purpose of the study was to investigate assessment knowledge developments of prospective mathematics teachers during the undergraduate education. The explanatory-confirmatory research design, one of the mixed research designs, was used in this study. The participants of the study consist of 176 prospective teachers in total, 44 of them being first-grade, 44 second-grade, 44 third-grade, and 44 fourth-grade students studying at the department of elementary school mathematics education of a university in Turkey. In this study, the assessment knowledge test consisting of ten questions, the interview, the observation were used as data collection tools to examine the assessment knowledge development of prospective teachers. Both qualitative and quantitative data analysis techniques were used during the data analysis process. The data on the classroom observations, interviews and knowledge test were presented in the study as direct quotations. As a result, it was found that the assessment knowledge of the prospective teachers was developed as directly proportional depending on the class level but this development was insufficient. Moreover, prospective teachers preferred traditional measurement-evaluation approaches more in their lesson practices. At the same time, it was observed prospective teachers did not benefit sufficiently from alternative measurement-evaluation approaches.
\end{abstract}

Keywords: pedagogical content knowledge, assessment knowledge, prospective teacher.

ÖZ: $\mathrm{Bu}$ çalışmada ilköğretim matematik öğretmeni adaylarının ölçme-değerlendirme bilgilerinin lisans eğitimleri boyunca nasıl bir gelişim gösterdiğinin incelenmesi amaçlanmıştır. Bu araştırmada karma araştırma desenlerinden açıklayıc1-doğrulayıcı araştırma deseni kullanılmıştır. Bu çalışmanın katılımcılarını; amaçsal örneklem yöntemiyle seçilen, bir üniversitenin eğitim fakültesinin ilköğretim matematik öğretmenliği bölümünde öğrenim gören 44 birinci, 44 ikinci, 44 üçüncü ve 44 dördüncü sınıf olmak üzere toplam 176 öğretmen adayı oluşturmaktadır. Bu çalışmada öğretmen adaylarının ölçme-değerlendirme bilgi gelişimlerini incelemek amacıyla mülakat, gözlem ve on sorudan oluşan ölçme-değerlendirme bilgi testi veri toplama aracı olarak kullanılmıştır. Çalışmadan elde edilen verilerin analizinde nitel ve nicel veri analiz teknikleri bir arada kullanılmıştır. Çalışmanın geçerliğini artırmak için öğretmen adaylarının bilgi testine verdikleri cevaplardan, mülakatlardan ve gözlemlerden doğrudan alıntılara yer verilmiştir. Çalışma sonunda öğretmen adaylarının ölçme-değerlendirme bilgilerinin sınıf düzeyiyle doğru olarak geliştiği fakat bu gelişiminin yetersiz olduğu sonucu ortaya çıkmıştır. Ayrıca çalışma sonunda; öğretmen adaylarının sınıf içi gözlemlerde daha çok geleneksel ölçme-değerlendirme yaklaşımlarını tercih ettikleri görülmüştür. Buna karşın öğretmen adaylarının alternatif ölçme-değerlendirme yöntemlerini ise kullanmakta zorlandıkları sonucuna ulaşılmıştır.

Anahtar kelimeler: pedagojik alan bilgisi, ölçme-değerlendirme bilgisi, öğretmen adayı.

\footnotetext{
** Corresponding Author: Asst. Prof. Dr., Amasya University, Amasya, Turkey, mersahin60@ gmail.com

**** Prof. Dr., Atatürk University, Erzurum, Turkey, yasinsoylu@ gmail.com
}

Citation Information

Şahin, Ö., \& Soylu, Y. (2019). Matematik öğretmeni adaylarının ölçme ve değerlendirme bilgi gelişimleri. Kuramsal Eğitimbilim Dergisi [Journal of Theoretical Educational Science], 12(1), 47-76. 


\section{Giriş}

1980’li y1llarda Amerika Bileşik Devletleri eğitim sisteminde meydana gelen sorunlar nedeniyle bir öğretmende bulunması gereken mesleki yeterlikler yoğun bir şekilde tartışılmaya başlanmıştır (Cochran, DeRuiter, \& King, 1993). ABD eğitim sisteminin nasıl düzeltileceğinin tartışıldığ 1 ve Lee Shulman'ın başkanlık ettiği Eğitim Araştırmaları Derneğinin bir toplantısı sırasında "Pedagojik Alan Bilgisi (PAB)" kavramı ilk defa ortaya çıkmıştır (Marks, 1990). Shulman (1987) pedagojik alan bilgisi kavramını merkeze alarak bir öğretmenin ihtiyaç duyacağı mesleki bilgi ve becerileri tanımladığ1 bir model geliştirmiştir (Cochran ve diğerleri, 1993). Shulman (1987) tarafından geliştirilen öğretmen bilgi modelinde; alan bilgisi (content knowledge), pedagojik alan bilgisi (pedagogical content knowledge), diğer içerik bilgileri (other content knowledge), öğrenci bilgisi (knowledge of learners), program bilgisi (curriculum knowledge), eğitim ortamı bilgisi ve genel pedagoji (general pedagogical knowledge) bilgisi olmak üzere yedi bilgi türünden bahsetmiştir. Shulman (1987) modelinde $\mathrm{PAB}$, öğrencileri anlama bilgisi ve öğretim stratejileri bilgisi olmak üzere iki alt bileşenden oluşmaktadır.

Shulman (1987) tarafından geliştirilen modelden esinlenen eğitim araştırmacıları farklı öğretmen bilgi modelleri ortaya koymuşlardır. Aşağıda yer alan Tablo 1'de görüldüğü üzere, araştırmacılar PAB kavramını farklı şekillerde yorumlamışlardır. Diğer bir ifadeyle, geliştirilen modellerde PAB'ın sınıflandırılmasında farklı alt bileşenlere yer verilmiştir (Park \& Oliver, 2008). Shulman (1987) ve birkaç öğretmen bilgi modelinde (Cochran ve diğerleri, 1993; Grossman, 1990; Marks, 1990; Smith \& Neale, 1989) ölçme-değerlendirme bilgisine PAB alt bileşeni olarak yer verilmemiştir. Buna rağmen bazı öğretmen bilgi modellerinde (Hasweh, 2005; Magnusson, Krajcik, \& Borko, 1999; Tamir, 1988) ölçme-değerlendirme bilgisine PAB alt bileșeni olarak yer verilmiştir. Bu bağlamda, ilgili literatürde ölçme ve değerlendirme bilgisine beklenilen şekilde önem verilmediği görülmektedir. Ölçme-değerlendirme bilgisini tanımlamadan önce bu bilgiye PAB alt bileşeni olarak yer veren $\mathrm{PAB}$ modellerini inceleyelim.

Hasweh (2005), PAB'1 yeniden sinıflamak amaciyla önceki PAB modellerini incelemiştir. Bunun neticesinde Hasweh (2005) PAB'1 Shulman (1987) gibi; ne alan bilgisinin ne de genel pedagoji bilgisinin bir alt bileşeni olabileceğinin aksine bu iki bilginin birbirine entegre olması sonucu oluşan yeni bir bilgi türü olarak tanımlamıştır. Hasweh (2005) öğretmenin pedagojik yapısını (Teacher Pedagogical Consruction-TPC) analiz ettiği çalışmasında PAB; alan bilgisi, öğrenci bilgisi, program bilgisi, bağlam bilgisi, öğretim strateji bilgisi, değerlendirme bilgisi, öğretim amaçları bilgisi ve genel pedagoji bilgisi alt bileşenlerinden oluşmaktadır.

Tamir (1988) geliştirmiş olduğu öğretmen bilgi modelinde, pedagojik alan bilgisi kavramını; öğrenci anlama bilgisi, öğretim strateji bilgisi, ölçme bilgisi ve program bilgisi olmak üzere dört alt kategoride sınıflamıştır. Ayrıca, Tamir'in (1988) geliştirmiş olduğu pedagojik alan bilgisi modelinde alan bilgisi pedagojik alan bilgisinin bir alt bileşeni olarak ele alınmamıştır. Bu modelde, Shulman (1987) da olduğu gibi öğrencileri anlama bilgisi ve öğretim strateji bilgisi pedagojik alan bilgisinin alt bileşeni olarak ele alınmaktır. Fakat Shulman (1987) ölçme-değerlendirme bilgisine modelinde yer vermezken Tamir (1988) PAB'ın bir alt bileşeni olarak yer vermiştir. 
Tablo 1

PAB Bileşenlerinin Farklı Kavramsallaştırılması (Park \& Oliver, 2008, s. 265).

\begin{tabular}{|c|c|c|c|c|c|c|c|c|c|}
\hline Araştırmacılar & 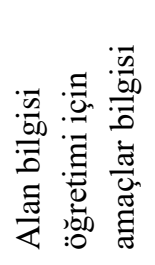 & 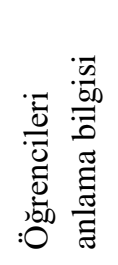 & $\begin{array}{l}\cdot \overline{5} \\
\frac{5}{60} \\
\overline{0} \\
0 \\
\bar{E} \\
0 \\
0 \\
0\end{array}$ & 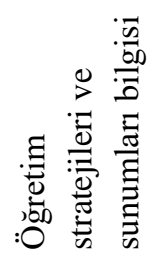 & 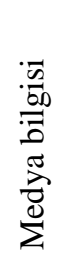 & 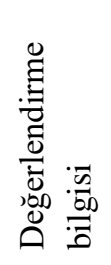 & $\begin{array}{l}\bar{a} \\
\frac{\overrightarrow{00}}{\overline{0}} \\
\overline{0} \\
\frac{\vec{\sigma}}{2}\end{array}$ & 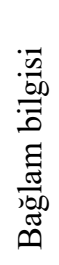 & 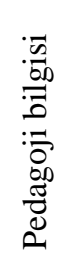 \\
\hline Shulman (1987) & $\mathrm{D}$ & $\mathrm{O}$ & $\mathrm{D}$ & $\mathrm{O}$ & & & $\mathrm{D}$ & $\mathrm{D}$ & $\mathrm{D}$ \\
\hline Tamir (1988) & & $\mathrm{O}$ & $\mathrm{O}$ & $\mathrm{O}$ & & $\mathrm{O}$ & $\mathrm{D}$ & & D \\
\hline Grossman (1990) & $\mathrm{O}$ & $\mathrm{O}$ & $\mathrm{O}$ & $\mathrm{O}$ & & & $\mathrm{D}$ & & \\
\hline Marks (1990) & & $\mathrm{O}$ & & $\mathrm{O}$ & $\mathrm{O}$ & & $\mathrm{O}$ & & \\
\hline $\begin{array}{l}\text { Smith ve Neale } \\
\text { (1989) }\end{array}$ & $\mathrm{O}$ & $\mathrm{O}$ & & $\mathrm{O}$ & & & $\mathrm{D}$ & & \\
\hline $\begin{array}{l}\text { Cochran vd. } \\
\text { (1993) }\end{array}$ & & $\mathrm{O}$ & & $\mathrm{N}$ & & & $\mathrm{O}$ & $\mathrm{O}$ & $\mathrm{O}$ \\
\hline Geddis (1993) & & $\mathrm{O}$ & $\mathrm{O}$ & $\mathrm{O}$ & & & & & \\
\hline $\begin{array}{l}\text { Fernandez- } \\
\text { Balboa ve }\end{array}$ & $\mathrm{O}$ & $\mathrm{O}$ & & $\mathrm{O}$ & & & $\mathrm{O}$ & $\mathrm{O}$ & \\
\hline Stiehl (1995) & & & & & & & & & \\
\hline $\begin{array}{l}\text { Magnusson vd. } \\
\text { (1999) }\end{array}$ & $\mathrm{O}$ & $\mathrm{O}$ & & $\mathrm{O}$ & & $\mathrm{O}$ & & & \\
\hline Hasweh (2005) & $\mathrm{O}$ & $\mathrm{O}$ & $\mathrm{O}$ & $\mathrm{O}$ & & $\mathrm{O}$ & $\mathrm{O}$ & $\mathrm{O}$ & $\mathrm{O}$ \\
\hline $\begin{array}{l}\text { Loughran vd. } \\
\text { (2006) }\end{array}$ & $\mathrm{O}$ & $\mathrm{O}$ & & $\mathrm{O}$ & & & $\mathrm{O}$ & $\mathrm{O}$ & $\mathrm{O}$ \\
\hline
\end{tabular}

D: Yazar bu kategoriyi $P A B$ ' in dışında ayrı bir kategori olarak ele almıştır.

O: Yazar bu kategoriyi $P A B^{\prime}$ in alt bileşeni olarak ele almıştır.

N: Yazar bu alt kategoriyi açı k bir şekilde tartışmamıştır. (Boş kısımlarla eşdeğer olup vurgu için kullanılmıştır.

Magnusson ve diğerleri (1999) yaptıkları çalışmada pedagojik alan bilgisi kavramını daha önce geliștirilmiș olan Grossman (1990) ve Tamir (1988) modellerini dikkate alarak yeniden ele almışlardır. $\mathrm{Bu}$ modelde PAB kavramı; program bilgisi (knowledge of science curriculum), değerlendirme bilgisi (knowledge of assessment in science), öğretim stratejileri bilgisi (knowledge of instructional strategies), öğrenci bilgisi (knowledge of students' understanding of science) ve fen öğretimi için amaçlar bilgisi (orientations toward teaching science) alt bileşenlerinden oluşmaktadır.

İlgili literatürde ölçme-değerlendirme bilgisi; bir öğretmenin bir öğrenme alanı ile ilgili öğrencilerinin ön bilgilerini, öğrenme düzeylerini, kavram yanılgılarını ve öğrenme zorluklarını ortaya çıkarmada kullanılan yöntemleri ve tekniklere dönük bilgisi şeklinde tanımlanmıştır (Baki, 2012; Hasweh, 2005; Magnusson ve diğerleri, 1999; Tamir, 1988). Bir başka ifadeyle ölçme-değerlendirme bilgisi, öğretmenin ölçmedeğerlendirmenin ve yöntemlerinin amaçlarını bilmesi, bunları kullanabilmesi, yeni araçlar geliştirebilmesi ve bu araçlarla topladıkları verileri analiz etmeye ve değerlendirmeye yönelik bilgisi olarak tanımlanabilir (Baştürk \& Dönmez, 2011). Dolayısıyla, ölçme ve değerlendirme bilgi düzeyleri yüksek olan öğretmenlerin 
öğrencilerinin yaptıkları hataları ve kavram yanılgılarını tespit edebilecek, onlara gerekli dönütleri verebilecektir. Ayrıca, bu öğretmenler öğrencilerinin ön bilgi düzeylerini, öğrenme eksiklerini ve bilgi düzeylerini gerçekçi bir şekilde belirleyerek onların konuları daha iyi öğrenmelerine yardımcı olacaklardır. Bundan dolayı eğitimöğretim faaliyetlerinin etkili bir şekilde gerçekleştirilmesinde öğretmenlerin sahip oldukları ölçme ve değerlendirme bilgisi önemli bir rol oynamaktadır (Hasweh, 2005; Magnusson ve diğerleri, 1999; Tamir, 1988).

Ölçme-değerlendirme bilgisinin öneminin bir göstergesi de yenilenen matematik dersi öğretim programıdır (Millî Eğitim Bakanlığı [MEB], 2017a). Yenilenen matematik ders öğretim programında ölçme-değerlendirmenin temel felsefesi şu şekilde ifade edilmiştir:

Öğretim programlarında öğrencilerin süreç içerisinde izlenmesi, yönlendirilmesi, öğrenme
güçlüklerinin belirlenerek giderilmesi, öğrencilerde anlamlı ve kalıcı öğrenmenin
desteklenmesi amacıyla sürekli geri bildirimin sağlanmasına yönelik bir ölçme
değerlendirme anlayışı benimsenmiştir. Elde edilen sayısal değerlerin anlam kazanabilmesi
için öğrencilerin gelişiminin izlenmesi ve bu gelişime bağlı olarak yönlendirilmesi,
programlarda önemsenen ilkeler arasındadır (MEB, 2017a, s.10).

Yenilen matematik dersi öğretim programı; öğretmen ve öğretmen adaylarından öğrencileri bütüncül ve çok yönlü olarak değerlendirilmelerini beklemektedir. Bundan dolayı, öğretmenler ve öğretmen adayları ölçme değerlendirmenin sadece not verme amaçlı değil aynı zamanda öğrencinin gelişiminin ve öğrenme sürecinin değerlendirilmesi amacıyla yapıldığının farkında olmalıdırlar. Dolayısıyla matematik öğretmen ve öğretmen adayları sadece yazılı, sözlü ve soru-cevap gibi geleneksel ölçme ve değerlendirme yöntemlerinin yanında portfolyo, tanılayıcı dallanmış ağaç, kavram haritası, yapılandırılmış grid gibi alternatif ölçme-değerlendirme yöntemlerini kullanabilecek yeterliğe sahip olmalıdırlar. Ayrıca öğretmen ve öğretmen adayları öğrencilerin sadece bilişsel özellikleri değil bunun yanında duyuşsal ve devinişsel özelliklerini de nasıl ölçecekleri ve değerlendireceklerini de bilmeleri gerekmektedir (MEB, 2017a). Bu bağlamda ölçme ve değerlendirme bilgisinin yenilenen matematik dersi öğretim programının hedeflediği kazanımları gerçekleştirilmesinde önemli bir konuma sahip olduğu söylenebilir. Fakat ilgili literatürde (Baumert ve diğerleri, 2010; Gökkurt, Şahin, \& Soylu, 2016; Jenkins, 2010; Kleickmann ve diğerleri, 2013; Şahin, Erdem, Başıbüyük, Gökkurt, \& Soylu, 2014; Şahin, 2016; Şahin, Gökkurt \& Soylu, 2016; Tanışlı \& Köse, 2013) öğretmen ve öğretmen adaylarının mesleki yeterliklerin gelişimlerine yönelik örnek çalışmalar incelendiğinde araştırmacıların daha çok alan bilgisi, öğrencileri anlama bilgisi ve öğretimsel stratejiler bilgisi bileşenlerine odaklandıkları görülmüştür. Diğer bir ifadeyle, pedagojik alan bilgisi literatüründe, PAB alt bileşenlerinden ölçme-değerlendirme bilgisi üzerine ise daha az çalışma (Ashraf \& Zolfaghari, 2018; Baştürk \& Dönmez, 2011; Birgin \& Gürbüz, 2008; Gökkurt, 2014; Mede \& Atay, 2017; Özenç, 2013; Tünkler \& Güven, 2018) yer almaktadır.

Ashraf ve Zolfaghari (2018) lisans eğitimi sonunda öğretmen adaylarının ölçme okuryazarlıklarının istenilen düzeye ulaşmadığını ifade etmiştir. Birgin ve Gürbüz (2008) ve Baştürk ve Dönmez (2011) öğretmen adaylarının öğrencilerin başarısını ve performansını belirlemede yazılı yoklama, çoktan seçmeli test ve soru-cevap tekniği gibi geleneksel yöntemleri kullanma eğiliminde olduklarını ve alternatif değerlendirme yöntemleri konusundaki bilgilerinin ise yeterli olmadığı sonucunu ortaya koymuşlardır. 
Özenç (2013) sınıf öğretmenlerinin alternatif ölçme ve değerlendirme bilgi düzeyleri orta seviyede olduğu sonucuna ulaşmıştır. Gökkurt (2014) ise matematik öğretmenlerinin ölçme-değerlendirmenin amacına ve alternatif ölçme-değerlendirme tekniklerine ilişkin bilgilerinin sınırlı olduğunu ifade etmiştir. İlgili literatürden örnek verilen bu çalışmaların (Ashraf \& Zolfaghari, 2018; Baştürk \& Dönmez, 2011; Birgin \& Gürbüz, 2008; Gökkurt, 2014; Özenç, 2013) sonuçları öğretmen ve öğretmen adaylarının daha çok geleneksel ölçme-değerlendirme yaklaşımlarını tercih ettikleri sonucuna ulaşılmıştır. Buna karşın öğretmen ve öğretmen adaylarının alternatif ölçmedeğerlendirme yaklaşımlarına dönük ise yeterince bilgi sahibi olmadıkları belirtilmiştir. Ölçme-değerlendirme bilgisinin öğrenci başarısı üzerindeki etkisi ve önemi, ayrıca ilgili literatürde ölçme-değerlendirme bilgisine yeterince yer verilmemesi ve mevcut literatürde yer alan çalışmaların sonuçları bu araştırmayı gerekli ve önemli kılmaktadır. Çünkü bu çalışma, öğretmenlik mesleğine yönelik temel eğitimin alındığı lisans öğrenimi sırasında ölçme ve değerlendirme bilgisinin nasıl bir gelişim gösterdiği ve bu gelişimin hangi düzeye ulaştığı hakkında ilgili kişilere ve kurumlara bilgi sağlayacaktır. $\mathrm{Bu}$ bağlamda çalışmanın amacı ilköğretim matematik öğretmeni adaylarının PAB alt bileşenlerinden ölçme-değerlendirme bilgi gelişimlerini incelemektir.

\section{Yöntem}

$\mathrm{Bu}$ araştırmada öğretmen adaylarının PAB alt bileşenlerinden ölçmedeğerlendirme bilgi gelişimlerini incelemek amacıyla karma araştırma desenlerinden açıklayıcı-doğrulayıcı (explanatory-confirmatory) araştırma deseni (Nicel $\rightarrow$ Nitel) kullanılmıştır. Açıklayıcı-doğrulayıcı araştırma deseninde; ilk olarak nicel veriler toplanır ve analiz edilir. Analiz edilen nicel veriler ölçüt alınarak nitel çalışma için katılımcılar seçilir ve bu katılımcılardan nitel veriler elde edilir. Açıklayıcı-doğrulayıcı araştırma deseninde; nicel veriler genel çerçeveyi ortaya çıkarır. Daha sonra elde edilen nitel veriler yardımıyla oluşan genel çerçeve daha anlamlı bir hale getirilir (Creswell, 2011; Johnson \& Christensen, 2004; McMillan \& Schumacher, 2010).

$\mathrm{Bu}$ çalışmanın nicel verilerinin elde edilmesi sürecinde deneysel olmayan araştırma desenlerinden enlemesine (kesitsel) araştırma yöntemi (cross-sectional comparative study) kullanılmıştır. $\mathrm{Bu}$ araştırma deseninin seçilmesindeki amaç; bir gruptan uzun süre veri toplamanın zor olmasıdır. Çünkü boylamsal çalışmalarda bir grubu uzun süre takip etmek gerekir. Bundan dolayı hem örneklem kaybı olma ihtimali hem de uzun zaman olması araştırmanın gerçekleşmesini zorlaştırmaktadır. Enlemesine araştırma yönteminde ise aynı anda eşdeğer gruplardan veri toplanabilmektedir (McMillan \& Schumacher, 2010). Bu çalışmanın nitel kısmında ise durum çalışması yöntemi kullanılmıştır. Durum çalışması yönteminde; araştırmacılar az sayıda katılımcı ile bir olayı, olguyu, durumu, ilişkiyi veya süreci, detaylı bir şekilde inceleyebilir (Denscombe, 2010).

\section{Katılımcilar}

$\mathrm{Bu}$ çalışmanın katılımcılarını; amaçsal örneklem yöntemiyle seçilen, Türkiye'nin Orta Karadeniz Bölgesi'nde yer alan ve 40 yılın üzerinde öğretmen yetiştirme birikimine sahip bir üniversitenin eğitim fakültesinin ilköğretim matematik öğretmenliği bölümünde öğrenim gören 44 birinci, 44 ikinci, 44 üçüncü ve 44 dördüncü sınıf olmak üzere toplam 176 öğretmen adayı oluşturmaktadır. Amaçsal örnekleme 
yönteminde; katılımcıların belirlenmesinde, araştırmanın amacı doğrultusunda bir takım kriterler dikkate alınır (Patton, 1987). Bu çalışmada kullanılan ölçüt ise, katılımcıların mesleki yeterlikleri arasında ölçme ve değerlendirme bilgisinin yer almasıdır. Çünkü Milli Eğitim Bakanlığının 2017 yılında yayımlamış olduğu “Öğretmenlik Mesleği Genel Yeterlikleri” kılavuzunda ve Matematik Dersi Öğretim Programı’ nda (2017a) ölçme ve değerlendirme bilgisine yer vermiştir.

Tablo 2

Öğretmen Adaylarının Demografik Özellikleri

\begin{tabular}{|c|c|c|c|c|c|}
\hline \multirow{2}{*}{ Demografik Özellikler } & & \multicolumn{4}{|c|}{ Sınıf Düzeyleri } \\
\hline & & 1.Sinıf & 2.Sinif & 3.Sinif & 4.Sinif \\
\hline \multirow{2}{*}{ Cinsiyet } & Erkek & 13 & 13 & 13 & 13 \\
\hline & $\mathrm{K} 1 \mathrm{z}$ & 31 & 31 & 31 & 31 \\
\hline \multirow{3}{*}{ Sosyo-Ekonomik Düzey } & İyi & 6 & 5 & 6 & 8 \\
\hline & Orta & 36 & 38 & 37 & 36 \\
\hline & Kötü & 2 & 1 & 1 & - \\
\hline \multirow[t]{2}{*}{ Mezun Olunan Lise Türü } & Öğretmen Lisesi & 24 & 15 & 11 & 8 \\
\hline & Diğerleri & 20 & 29 & 33 & 36 \\
\hline \multirow[t]{5}{*}{ Babanın Eğitim Durumu } & Okula Gitmemiş & - & - & - & 2 \\
\hline & İlkokul & 15 & 15 & 12 & 17 \\
\hline & Ortaokul & 6 & 4 & 6 & 9 \\
\hline & Lise & 10 & 15 & 10 & 9 \\
\hline & Üniversite & 13 & 10 & 16 & 7 \\
\hline \multirow[t]{5}{*}{ Annenin Eğitim Durumu } & Okula Gitmemiş & 1 & 1 & 6 & 8 \\
\hline & İlkokul & 29 & 25 & 29 & 23 \\
\hline & Ortaokul & 2 & 7 & 4 & 5 \\
\hline & Lise & 10 & 8 & 5 & 6 \\
\hline & Üniversite & 2 & 3 & - & 2 \\
\hline \multirow[t]{4}{*}{ Bölüm Tercih Sırası } & $1-5$ & 29 & 28 & 31 & 35 \\
\hline & $5-10$ & 10 & 9 & 6 & 4 \\
\hline & $10-15$ & 4 & 7 & 3 & 4 \\
\hline & $15-20$ & 1 & - & 1 & 1 \\
\hline \multirow[t]{3}{*}{ Bölüm Tercih Nedeni } & İdealist & 16 & 20 & 18 & 16 \\
\hline & Atama Kolaylığı & 23 & 18 & 25 & 20 \\
\hline & Aile Baskısı & 5 & 6 & 1 & 8 \\
\hline
\end{tabular}

Çalışmada enlemesine araştırma deseni kullanıldığı için grupların birbirine yakın olmasını sağlama açısından aynı üniversitede öğrenim gören öğretmen adaylarının seçilmesi önem kazanmaktadır. Çalışmaya katılan öğretmen adaylarının birbirine 
eşdeğer gruplar oluşturması için sayısal olarak birbirine yakın olmasına, kız-erkek sayısının eşit dağılmasına, bölüm tercih nedenlerinin benzer olmasına, ailesinin eğitim durumlarına dikkat edilmiştir. Çalışmaya katılacak öğretmen adaylarını belirlemek amacıyla ilk önce öğretmen adaylarının demografik özelliklerini ölçen bir form uygulanmıştır. Katılımcıların belirlenmesinde ilk olarak, öğretmen adaylarının cinsiyet değişkeni açısından birbirine sayısal olarak eşit olmalarına dikkat edilmiştir. Çünkü öğretmenlerin mesleki gelişimleri üzerine yapılan birçok çalışmada (Gökbulut, 2010; Kleickmann ve diğerleri, 2013; Stephens, 2006) cinsiyet değişkeni katılımcıların seçiminde dikkate alınmıştır. Bu çalışmada her sınıf düzeyinde, $31 \mathrm{kız}$ ve 13 erkek olmak üzere toplam 44 öğrenci yer almaktadır. Ayrıca Tablo 2'den görüldüğü üzere; anne-baba eğitim durumu, mezun olunan lise, sosyo-ekonomik düzey, bölüm tercih sırası ve bölüm tercih nedeni gibi değişkenler açısından da öğretmen adaylarının sayısal olarak birbirine yakın oldukları görülmektedir. Sınıf düzeyine göre eş değer gruplar oluşturulduktan sonra araştırmacı tarafından geliştirilen veri toplama araçları öğretmen adaylarına uygulanmıştır.

Araştırmanın etiği çerçevesinde çalışmaya katılan öğretmen adaylarının gerçek isimleri yerine kodlar kullanılmıştır. Çalışmayan katılan 1. sınıf öğrencileri $1 S 1$ 'den $1 S 44^{\prime}$ 'e, 2. sinıf öğrencileri $2 S 1$ 'den $2 S 44$ 'e, 3. sinıf öğrencileri $3 S 1$ 'den $3 S 44^{\prime}$ 'e ve 4. sınıf öğrencilerine ise $4 S 1$ 'den $4 S 44$ 'e kadar kodlanmıştır.

\section{Nicel Veri Toplama Araçları}

$\mathrm{Bu}$ çalışmada öğretmen adaylarının ölçme ve değerlendirme bilgi gelişimlerini incelemek amacıyla nicel veri toplama araçlarından ölçme-değerlendirme bilgi testi kullanılmıştır.

Ölçme-Değerlendirme Bilgi Testi (ÖDBT). Bu çalışmada öğretmen adaylarının PAB bileşenlerinden ölçme-değerlendirme bilgi düzeylerini belirlemek amaciyla toplam on sorudan oluşan ÖDBT (Ek-1) kullanılmıştır. ÖDBT hazırlanırken ilk olarak araştırmacı tarafından on sorudan oluşan bir soru havuzu oluşturulmuşstur. Geliştirilen bilgi testinin kapsam geçerliğini kontrol etmek için; biri matematik eğitimi alanında, biri ölçme alanında ve biri dil alanında uzman üç akademisyenin görüşlerine başvurulmuştur. Daha sonra uzman görüşleri doğrultusunda soru sayısının yeterli olduğu ve herhangi bir sorunun testten çıkarılmadan on sorudan oluşan ÖDBT'nin öğretmen adaylarının ölçme-değerlendirme bilgilerini ölçmek amacıyla kullanılabileceği ifade edilmiştir. Fakat uzmanlar ÖDBT üçüncü sorusunda yer alan "ön bilgi" ifadesi yerine "hazırbulunuşluk" ifadesinin kullanılması gerektiğini ifade etmişlerdir. Ayrıca ÖDBT birinci sorusunun ilk cümlesi "Ders esnasında bir öğrencinizin matematik ile ilgili bir kavram hakkında kavram yanılgısına sahip olduğunu fark ettiniz." uzman görüşleri doğrultusunda "Herhangi bir öğrencinin matematik ile ilgili bir kavramda kavram yanılgısına sahip olup olmadığını belirlemek istiyorsunuz." şeklinde düzenlenmiştir. Bu bağlamda uzman görüşleri doğrultusunda düzenlenen ve on sorudan oluşan ÖDBT pilot uygulama çerçevesinde 65 öğretmen adayına uygulanmıştır. Pilot çalışma, geliştirilen testin uygulama süresinin tespit edilmesi, eksik ifade bulunduran veya anlaşılamayan soruların belirlenmesi, soru sayısının yeterli olup olmadığının belirlenmesi ve araştırmacının testleri değerlendirmede tecrübe kazanması amacıyla yapılmıştır. Pilot uygulama sonrası uzman 
görüşleri tekrar alınmış ve on sorudan oluşan ÖDBT'nin öğretmen adaylarının ölçmedeğerlendirme bilgilerini ölçmede kullanılabileceğine karar verilmiştir.

Bilgi testinde yer alan birinci soruda kavram yanılgılarını belirlemede, ikinci soruda farklı becerileri ölçmede, üçüncü soruda öğrencilerin hazırbulunuşluk düzeylerinin belirlenmesinde ve dördüncü soruda ise öğrencilerin bir ders sonunda öğrenme düzeylerinin belirlenmesinde hangi ölçme araçlarının kullanılması gerektiği sorulmaktadır. Beşinci soruda, öğretmen adaylarının alternatif ölçme ve değerlendirme yaklaşımlarına yönelik bilgileri ölçülmektedir. Altıncı soruda, öğretmen adaylarının verilen durumlara uygun ölçme aracını seçmeleri istenmiştir. Yedinci soruda ise, verilen ölçme araçlarının geçerli ve güvenilir olması için neler yapılması gerektiği sorulmuştur. Sekizinci soruda, öğretmen adaylarının madde güçlüğü ve madde ayırt ediciliği hakkındaki bilgilerinin ölçülmesi hedeflenmiştir. Dokuzuncu soruda, ölçme ve değerlendirmenin amaçlarının neler olduğu sorulurken, onuncu soruda ölçme ve değerlendirmenin eğitim sürecinin hangi aşamalarında niçin yapıldığg sorulmuştur.

\section{Nitel Veri Toplama Araçları}

$\mathrm{Bu}$ çalışmada öğretmen adaylarının ölçme ve değerlendirme bilgi gelişimlerini incelemek amacıyla nitel veri toplama araçlarından mülakat, gözlem ve dökümanlar kullanılmıştır.

Mülakat. Veri toplama sürecinde her sınıf düzeyinden 4-5 öğretmen adayı ile 26 dakika uzunluğunda yarı-yapılandırılmış mülakatlar yapılmıştır. Bu çalışmada mülakat yapılacak öğretmen adaylarının belirlenmesinde; öğretmen adaylarının bilgi testine verdikleri cevaplar dikkate alınmıştır. Mülakatlar öğretmen adaylarının tam doğru cevaba ulaşmakta zorlandıkları sorularda yoğunlaşmıştır. Diğer bir ifadeyle, kısmen doğru (b) ve yanlış kategorilerinde cevap veren öğretmen adaylarıyla mülakatlar yapılmıştır. Bu bağlamda 1S8 öğretmen adayı ile yapılan mülakata aşağıda yer verilmişstir.

\section{Şekil 1. 1S8 Öğretmen Adayının Beşinci Soruya Verdiği Cevap}
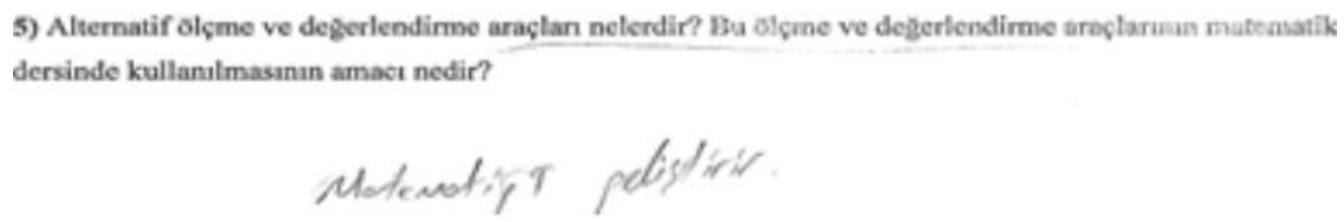
A: Alternatif ölçme-değerlendirme araçlarının amacı olarak "matematĭ̆i geliş̧tirir."
demişsin. Peki, alternatif ölçme-değerlendirme araçlarına örnek verebilir misin?

1S8: Yazıll sinavlar, materyaller de olabilir. Tahta. Öğrencilerin getirdiği malzemeler.

A: Peki alternatif ölçme-değerlendirmenin amacı nedir?

1S8: Görsellik açısından öğrenci daha iyi kavrayabilsin diye kullanırı.

A: Peki geleneksel ölçme-değerlendirme ile alternatif ölçme-değerlendirmenin farkı nedir?

1S8: Geleneksel, ögrretmenin standart anlattı̆̆ ölçme- değerlendirme olabilir.

A: Standart?

1S8: Sadece konuşmaya bağll, düz okuyup geçer. 
1S8 öğretmen adayı bilgi testinde yer alan beşinci soruya yanlış cevap vermiştir. Öğretmen adayının cevabını anlamlandırma amacıyla yapılan mülakat sırasında da öğretmen adayının alternatif ölçme-değerlendirme hakkında yanlış bilgilere sahip olduğu görülmüştür.

Gözlem ve Dökümanlar. Bu çalışmada da öğretmen adaylarının bilgi testine vermiş oldukları yazılı ve sözlü cevapların ders uygulamalarına yansımalarını görmek amacıyla yapılandırılmış bir gözlem formu (Ek-2) yardımıyla gözlemler gerçekleştirilmiştir. Ders uygulamalarına katılacak öğretmen adaylarının seçiminde alttan derslerinin olmamasına ve bilgi testi puanlarının sınıf ortalamalarını temsil etmesine dikkat edilmiştir. Gözlem yapılacak öğretmen adaylarının sınıf düzeyine göre birbiriyle paralel gruplar oluşturması hedeflenmiştir. Öğretmen adayları Milli Eğitim Bakanlığı'na bağlı bir ortaokulda, gerekli yasal izinler alındıktan sonra gerçek sınıf ortamında ikişer ders saati öğretim faaliyetleri gerçekleştirmişlerdir.

Tablo 3

Gözlem Yapılan Öğretmen Adaylarının Bilgi Testinden Aldıkları Puanlar

\begin{tabular}{ccccccccc}
\hline Öğretmen Aday1 & $1 \mathrm{~S} 1$ & $1 \mathrm{~S} 13$ & $2 \mathrm{~S} 2$ & $2 \mathrm{~S} 21$ & $3 \mathrm{~S} 39$ & $3 \mathrm{~S} 41$ & $4 \mathrm{~S} 34$ & $4 \mathrm{~S} 44$ \\
\hline Cinsiyet & Erkek & K1z & Erkek & Kız & Erkek & Kız & Kız & Erkek \\
Bilgi Testi Puan1 & 12 & 13 & 16 & 20 & 22 & 24 & 29 & 22 \\
\hline
\end{tabular}

Matematik öğrenme ortamlarında yer alan birçok bileşenin aynı anda gözlemlenip kayıt altına alınmasının zor olacağı düşünüldüğü için gözlemlerin video kaydına alınması uygun görülmüştür. Ayrıca, gözlemler yapılırken gözlem formlarına notlar tutulmuştur. Geliştirilen gözlem formları alanında uzman iki akademisyen tarafından incelenmiştir. Uzmanların görüşleri doğrultusunda benzer anlama gelen veya çalışmanın amacına hizmet etmeyen maddeler gözlem formundan çıkarılmıştır. Öğretmen adaylarının ders anlatımlarından önce hazırladıkları ders planları da veri toplama araçlarının çeşitliliğini sağlamak için kullanılmıştır.

\section{Nicel Verilerin Analizi}

Öğretmen adaylarının ölçme-değerlendirme bilgi testine verdikleri cevapların analizinde; Kwong, Joseph, Eric, \& Khoh (2007) ve Şahin ve diğerleri' nin (2014) kullandıkları veri analiz çerçevelerinden yararlanılmıştır. Bu bağlamda Tablo 4'de ölçme-değerlendirme bilgi testi beşinci sorusuna ait veri analiz çerçevesi yer almaktadır.

Ölçme-değerlendirme bilgi testinde yer alan her bir soruya ait frekans-yüzde dağılım tabloları Ek-3'te yer almaktadır. Frekans-yüzde dağılım tablolarının oluşturulmasında öğretmen adaylarının teste vermiş oldukları cevapların puanlama kategorilerine göre dağılımı esas alınmıştır. Bu tablolar çok fazla yer kapladığı için bulgular kısmında ayrıca tablolar halinde verilmeyecektir. 
Tablo 4

Beşinci Soru Veri Analiz Çerçevesi

\begin{tabular}{|c|c|c|c|}
\hline Puan & $\begin{array}{l}\text { Puanlama } \\
\text { Kategorisi }\end{array}$ & Açıklama & Örnek Öğretmen Adayı Cevabı \\
\hline 4 & Tam Doğru & $\begin{array}{l}\text { Öğretmen adaylarının, soruya } \\
\text { tam doğru ve eksiksiz bir } \\
\text { şekilde cevap vermesi } \\
\text { durumudur. }\end{array}$ & $\begin{array}{l}\text { Proje ödevleri, performas ödevleri, öğrenci } \\
\text { ürün dosyaları, akran ve öz değerlendirme, } \\
\text { dereceli ölçekler, gözlemler, sunumlar, } \\
\text { sergiler. Amacı * Daha derin ve anlamlı } \\
\text { bilgiyi ölçme. * Öğrenme ürünü kadar } \\
\text { sürecinde değerlendirilmesi * Bilişsel, } \\
\text { duyuşsal, psiko-motor gelişimin üçünü } \\
\text { birden değerlendirilmesi. (4S36) }\end{array}$ \\
\hline 3 & $\begin{array}{l}\text { K1smen } \\
\text { Doğru (a) }\end{array}$ & $\begin{array}{l}\text { Öğretmen adaylarının, tam } \\
\text { doğru cevap veremediği fakat } \\
\text { sorunun cevabının doğruya } \\
\text { çok yakın olduğu, küçük } \\
\text { hatalar içerdiği durumlardır. }\end{array}$ & $\begin{array}{l}\text { Klasik ölçme araçlarının dışında, kavram } \\
\text { yanılgılarını tespit etmede ve gidermede } \\
\text { kullanılır. Portfolyo, kavram ağı, zihin } \\
\text { haritası, yapılandırılmış grid, V diyagramı } \\
\text { vb. (4S44) }\end{array}$ \\
\hline 2 & $\begin{array}{l}\text { Kismen } \\
\text { Doğru (b) }\end{array}$ & $\begin{array}{l}\text { Öğretmen adaylarının, } \\
\text { tamamen yanlış cevap } \\
\text { vermediği, yanlışa göre az da } \\
\text { olsa cevaplarında doğru } \\
\text { ifadelerin yer aldığı } \\
\text { durumlardır. }\end{array}$ & $\begin{array}{l}\text { Örneğin sözlü sınav yapmak. Proje ve } \\
\text { performans ödevleri. Öğrencinin farklı } \\
\text { yollardan bilgisini ölçmek. (2S37). }\end{array}$ \\
\hline 1 & Yanlış & $\begin{array}{l}\text { Öğretmen adaylarının } \\
\text { cevaplarının tamamen } \\
\text { yanlış/alakasız olması } \\
\text { durumudur. }\end{array}$ & $\begin{array}{l}\text { Cetvel, pergel. Şekilleri çizmemize yarar } \\
(1 \mathrm{~S} 17) . \\
\text { Yazılı sınav, sözlü sınav, çoktan seçmeli } \\
\text { test (2S39) }\end{array}$ \\
\hline 0 & Boş & $\begin{array}{l}\text { Öğretmen adaylarının soruya } \\
\text { herhangi bir cevap vermediği } \\
\text { durumlardır }\end{array}$ & ----------- \\
\hline
\end{tabular}

$\mathrm{Bu}$ çalışmada ölçme-değerlendirme bilgi testinin güvenirliğini kontrol etmek için iki farklı puanlayıcının yaptığı puanlamalar arasındaki uyum yüzdesi hesaplanmıştır. Puanlama güvenirliğinin kabul edilebilir olması için güvenirlik yüzdesinin en az \%70 düzeyinde olması gerekmektedir (Yıldırım \& Şimşek, 2011). Bu çalışmada, bilgi testinden elde edilen veriler ilk olarak iki araştırmacı tarafından, daha önce hazırlanan ve uzman görüşleri doğrultusunda düzenlenen cevap anahtarı yardımıyla puanlanmıştır. Daha sonra araştırmacılar bir araya gelerek yapılan kodlamaları karşılaştırmışlardır. Kodlamaların benzerlikleri ve farklılıkları sayısal olarak karşılaştırıldıktan sonra kodlama güvenirlik yüzdesi \%98 olarak hesaplanmıştır. Daha sonra araştırmacılar bir araya gelerek farklılaşma olan kodlamalar üzerinde uzlaşmaya vararak nicel veri analiz süreci tamamlanmıştır

$\mathrm{Bu}$ çalışmada, öğretmen adaylarının ölçme-değerlendirme bilgi gelişimlerini incelemek amacıyla parametrik mi yoksa parametrik olmayan bir test mi kullanılacağını belirlemek için verilerin normalliği kontrol edilmiştir. Verilerin normal dağılıp dağılmadığını kontrol etmede, örneklem büyüklüğü 176>50 olduğundan dolayı Kolmogorov-Smirnov testi kullanılmıştır. Ayrıca, $p$ değerinin $\alpha=0.05$ 'den küçük olması 
dağılımın normal olmadığını göstermektedir (Büyüköztürk, Kılıç-Çakmak, Akgün, Karadeniz, \& Demirel, 2011). Aşağıda yer alan Tablo 5 'te ölçme-değerlendirme bilgi testi puanlarına ait Kolmogorov-Smirnov testi sonuçları yer almaktadır.

Tablo 5

Kolmogorov-Smirnov Testi Sonuçları

\begin{tabular}{ccc}
\hline İstatistik & $\mathrm{df}$ & $\mathrm{p}(\mathrm{sig})$ \\
\hline 0.057 & 176 & 0.200
\end{tabular}

Tablo 5'te görüldüğü üzere p>.05 olduğundan, öğretmen adaylarının ölçmedeğerlendirme bilgi testi puanlarının normal dağıldığı söylenebilir. Bundan dolayı öğretmen adaylarının ölçme-değerlendirme bilgi testi puan ortalamalarının karşılaştırılmasında, parametrik testlerden biri olan Tek Yönlü Varyans Analiz (ANOVA) testi kullanılmıştır. Ayrıca, elde edilen nicel verilerin analizinde PASW Statistics Data Editor paket programı kullanılmıştır.

\section{Nitel Verilerin Analizi}

Wolcott (1994) nitel veri analizinde üç yaklaşım olduğunu ifade etmektedir. Birinci yaklaşım, elde edilen mülakat, gözlem vb. yollarla elde edilen nitel verilerin özgünlüklerinin bozulmadan doğrudan alıntılar yoluyla araştırmaya dahil edilmesidir. İkinci yaklaşım ise, bazı nedensel sonuçlara ulaşmak için sistematik bir analiz yapmaktır. Üçüncü yol da birinci ve ikinci yaklaşımı temel alarak araştırmacının kendi yorumlarını katmasıyla verilerin analiz edilmesidir. Bu sınıflandırmaya göre birinci ve ikinci yaklaşım betimsel analize, ikinci ve üçüncü yaklaşım ise içerik analizine ait öğeler içermektedir (Yıldırım \& Şimşek, 2011). Bu çalışmada öğretmen adaylarıyla yapılan görüşmelerin analizinde Wolcott'un (1994) birinci yaklaşımı esas alınmıştır. Dolayısıyla, öğretmen adaylarıyla yapılan mülakatlar doğrudan alıntılar şeklinde raporlaştııılmıştır. Öğretmen adaylarının sınıf içi gözlemlerine ait veriler için ise ikinci yaklaşım esas alınmıştır. Öğretmen adaylarının sınıf içi gözlemlerine ait veriler, gözlem formları doğrultusunda doğrudan alıntılar şeklinde araştırmada sunulmuştur.

\section{Bulgular}

Çalışmanın bu bölümünde veri toplama araçlarından elde edilen bulgular, tablolar ve doğrudan alıntılar yardımıyla sunulmuştur. Bulguların sunulmasında; ilk olarak ölçme-değerlendirme bilgi testine öğretmen adaylarının vermiş oldukları cevaplara ait her bir soruya ait nicel bulgulara (Ek-3) ve bulguları desteklemek için nitel bulgulara yer verilmiştir. En son aşamada ise öğretmen adaylarının bilgi testi toplam puanlarına ve ölçme-değerlendirme bilgi gelişimlerine ait bulgulara yer verilmiştir.

ÖDBT birinci sorusuna hiçbir öğretmen adayı tam doğru cevap verememiştir. Öğretmen adaylarının cevapları kısmen doğru (b) kategorisinde yoğunlaşmıştır. Dolayısıyla, öğretmen adaylarının öğrencilerin kavram yanılgılarının nasıl belirlenebileceğine dair yaptığı açıklamaların yetersiz olduğu söylenebilir. Ayrıca birinci ve ikinci sınıf öğretmen adaylarının ortaokul öğrencilerinin kavram yanılgılarının tespit edilmesinde genelde sadece yöntem ismi yazdı̆̆ fakat bu 
yöntemleri nasıl kullanabileceklerini ifade edemediklerini görülmüştür. Bu bağlamda 1S34 ve 2S44 öğretmen adaylarının cevapları aşağıda verilmiştir:

“Yazılı sınavı yapılabilir.”(1S34)

"Eğer öğrenci kavramı biliyorsa yeni konuya geçerim, bilmiyorsa o kavramı anlatırım." (2S44)

Öğretmen adaylarının ders gözlemleri sırasında da öğrencilerin kavram yanılgılarını belirlemekte zorlandıkları görülmüştür. Örneğin, 1S1 öğretmen adayı Öğretmen adayı tahtaya $3 x+2+2 x+5=$ ? şeklinde bir soru yazdıktan sonra bir öğrenciyi tahtaya kaldırdı. Daha sonra sınıf içinde gerçekleşen olaylar aşağıda verilmiştir:

Öğrenci 1: Önce x' leri toplayacağız bir, iki. İki tane x var.

1S13: Kaç tane $\mathrm{x}$ var?

Öğrenci 1: İki ( $x^{2}$ yazdı). Bunları toplayacağız, hepsini. Dört, beş, altı, yedi. Beşe eklersek on iki. $\left(12 \mathrm{x}^{2}\right.$ yazd1)

1S13: Arkadaşınız doğru yaptı mı? (Sınıfa dönerek)

Öğrenci 2: Doğru yaptı hocam.

1S13: Emin misiniz?

Öğrenci 3: Yanlış yaptı. (Öğretmen adayı yanlış yaptı diyen öğrenciyi tahtaya kaldırdı.)

Öğrenci 3: Bir $x$ değil $3 x$ var. Burada da $2 x$ var toplamda $5 x$ yazılır ( $x^{5}$ yazmıştır.). Geriye kalan sayıları toplayacağız iki ile beş yedi.

1S1 öğretmen adayı tahtaya çıkardığı ilk öğrencinin yaptığı kavram yanılgısını doğru bir şekilde belirleyip müdahale edememiştir. Bunun neticesinde tahtaya kalkan diğer öğrencide benzer bir kavram yanılgısına düşmüştür ve öğretmen adayı yine kavram yanılgısını belirleyememiştir.

ÖDBT ikinci sorusuna sadece dördüncü sınıf öğretmen adaylarının 4'ü (\%9.1) tam doğru cevap vermiştir. Birinci sınıf öğretmen adaylarının büyük bir kısmı bu soruya herhangi bir cevap vermemiştir. Ayrıca, öğretmen adaylarının büyük bir kısmı bu soruya kısmen doğru (b) kategorisinde cevap vermiştir. ÖDBT ikinci sorusuna ait bulgular, öğretmen adaylarının bilişsel özelliklerin hangi ölçme-değerlendirme yöntemleri ile ölçülebileceğini ifade etmekte zorlanmazken, duyuşsal ve psiko-motor becerilerin hangi ölçme-değerlendirme yöntemleri ile ölçülebileceği hakkında yeterli bilgiye sahip olmadıklarını göstermektedir. Örneğin 2S19 öğretmen adayı ile yapılan mülakattan görüldüğü üzere, öğretmen adayı bilişsel özelliklerin ölçülmesinde "yazılı veya test sınavlarının” kullanılabileceğini ifade etmiştir. Öğretmen adayı duyuşsal davranışlara örnek verebilirken, duyuşsal özelliklerin ise "sözlüye kaldırma" ile ölçülebileceğini ifade etmiştir. Ayrıca bu öğretmen adayı psiko-motor becerilerin hangi ölçme araçlarıyla ölçülebileceğine dair herhangi bir açıklama yapmamıştır.

Şekil 2. 2S19 Öğretmen Adayının İkinci Soruya Verdiği Cevap

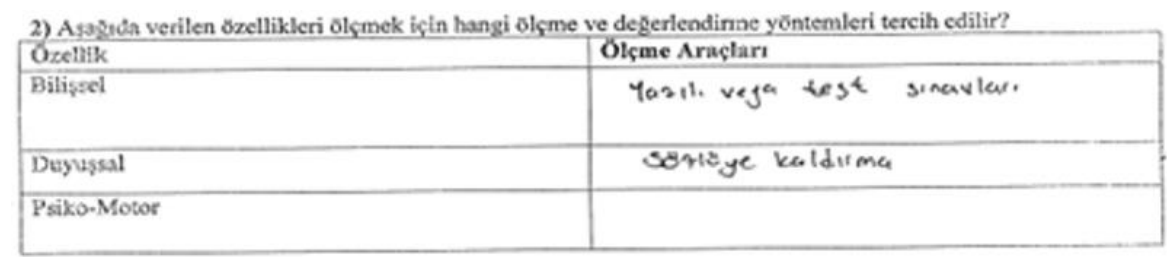

A: Bilişsel özellikleri ölçmede yazılı ve test sınavları dışında başka ölçme araçları var mı?

2S19: Bilmiyorum.

(C) 2019 AKU, Kuramsal Eğitimbilim Dergisi - Journal of Theoretical Educational Science, 12(1), 47-76 
A: Peki bilişsel nedir?

2S19: Bir bilginin bilinip bilinmediği. Verdiğimiz bilgilerin geri dönütü olarak zaten yazılı da, bu çalışma kağıtları olabilir, sonrasında vereceğimiz test çalışmaları olabilir.

A: Duyuşsal özellikleri ölçmede sözlüye kaldırma demişsin. Açıklar mısın?

2S19: O şekilde kendini ifade edebilir.

A: Duyuşsal deyince ne anliyorsun?

2S19: Duyuşsal, ona karşı ilgisi.

A: Matematikle ilgili duyuşsal bir özellik söyleyebilir misin?

2S19: Matematiği sevme.

A: Peki psiko-motor?

2S19: Psiko-motor derken onu matematikle pek bağdaştıramadım...

Öğretmen adaylarının ders anlatmadan önce hazırladıkları planlarda da sadece bilişsel özelliklerin ölçülmesine yönelik davranışlara yer verdikleri görülmektedir.

Şekil 3. 4S34 Öğretmen Adayının Ders Planının Ölçme Kısmı

\begin{tabular}{|c|c|}
\hline Olçme-Deß̌erlendirme & 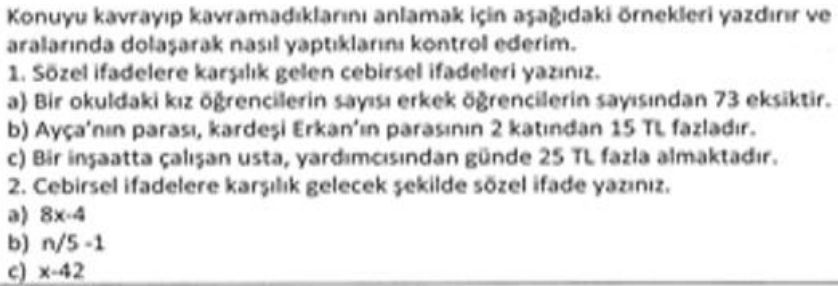 \\
\hline
\end{tabular}

ÖDBT üçüncü sorusuna hiçbir öğretmen adayı tam doğru cevap verememiştir ve öğretmen adaylarının cevaplarının kısmen doğru (b) kategorisinde yoğunlaştığ1 görülmektedir. ÖDBT üçüncü sorusuna ait bulgular, öğretmen adaylarının ortaokul öğrencilerinin hazır bulunuşluk düzeylerini belirlemeye yönelik yöntem-teknik bilgilerinin yetersiz olduğunu göstermektedir. 3S6 öğretmen aday1 "Geçmiş konulara ilişkin soru sorarım ve ĕger biliyorsa sonraki konu ile bağlantıll sorular sorarım." şeklinde verdiği cevap öğretmen adaylarının genel cevaplarını temsil etmektedir. Ayrıca öğretmen adaylarının öğrencilerin hazır bulunuşluk düzeylerini belirleme sürecini detaylı bir şekilde açıklayamadıkları da söylenebilir. Örneğin 2S28 öğretmen adayının yaptığı "Konиyu anlatmadan önce ön-test uygulayıp hangi seviyede olduklarını belirlerim." açıklama bu bulguyu desteklemektedir. Öğretmen adaylarının ders uygulamalarında da öğrencilerin hazır bulunuşluk düzeylerini belirlemek amacıyla yeterince çaba harcamadıkları görülmüştür. Öğretmen adayları öğrencilerin hazır bulunuşluk düzeylerinin belirlenmesinde genellikle soru-cevap tekniğinden yararlandıkları görülmüştür. 4S34 öğretmen adayı ise diğer öğretmen adaylarına ek olarak zihin haritasından yararlanmıştır. 
Şekil 4. 4S34 Öğretmen Adayının Kullandığı Zihin Haritasından Bir Kesit

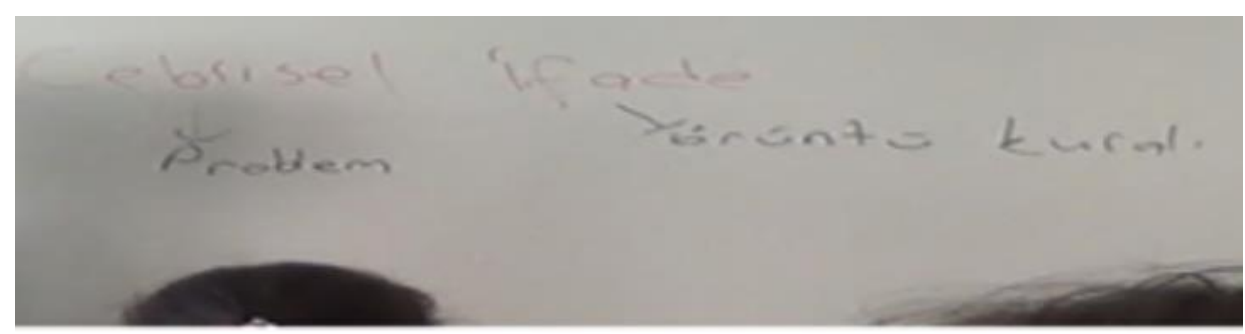

4S34 öğretmen adayı, öğrencilerin konuya dikkatlerini çekmek ve ön bilgi düzeylerini belirlemek amacıyla "Cebirsel ifade denilince aklınıza ne geliyor? Hiç gördünüz mü daha önce?" sorusuyla derse başlamıştır. Daha sonra öğretmen adayı öğrencilerin cebirsel ifade kavramı ile ilgili söyledikleri kavramları tahtaya yazarak bir zihin haritası oluşturmuşstur.

ÖDBT dördüncü sorusuna hiçbir öğretmen adayı tam doğru cevap verememiştir. ÖDBT dördüncü sorusunda öğretmen adaylarının cevaplarının kısmen doğru (b) kategorisinde yoğunlaştığı görülmektedir. ÖDBT dördüncü sorusuna ait bulgulardan, birinci ve ikinci sınıf öğretmen adaylarının öğrencilerin bir dersi anlayıp anlamadığını belirlemek için genelde soru sormayı tercih ettikleri söylenebilir. Fakat birinci ve ikinci sınıf öğretmen adayları kullanacakları ölçme-değerlendirme araçlarının ne olduğunu ifade edemedikleri görülmektedir. Örneğin 2S5 öğretmen aday1 "Konuyu anlattıktan sonra sorular sorarım." şeklindeki cevabında herhangi bir ölçme aracından bahsetmemiştir. Üçüncü ve dördüncü sınıf öğretmen adaylarının ise çok az sayıda ölçme arac1 örnek verebildiği görülmektedir. Örneğin 3S21 öğretmen adayının "Dersin sonunda hazırladı̆̆ım çalışma kâğıtlarını, öğrencilerin sınıf ortamında çözmelerini isterim. Bunun sonucunda değerlendiririm." açıklamasında sadece çalışma kâğıdından bahsedilmiştir. Öğretmen adayının açıklaması doğru olmasına rağmen zengin bir içeriğe sahip değildir.

ÖDBT beşinci sorusuna sadece dördüncü sınıf öğretmen adaylarının 2'si (\%4.5) tam doğru cevap vermiştir. Ayrıca dördüncü sınıf öğretmen adaylarının 23’ü (\%52.3) ve üçüncü sınıf öğretmen adaylarının 6'sı (\%13.6) kısmen doğru (a) kategorisinde cevap vermiştir. Birinci ve ikinci sınıf öğretmen adaylarının hiçbiri tam doğru ve kısmen doğru (a) kategorilerinde cevap verememiştir. Bu bağlamda öğretmen adaylarının örnek cevapları aşağıda verilmiştir:

\footnotetext{
"Matematiği geliştirir." (1S8)

"Test, klasik sınav. Çocukların hazır bulunuşluklarını belirlemek ya da konuyu ne kadar anladığını belirlemek.” (2S25)

"Performans ödevi, proje, kavram haritaları, akran değerlendirme." (3S22)

"Gözlem, mülakat, anektod, kontrol listesi, rubrik, portfolyo. Amaç öğrencinin öğrenme motivasyonunu artırmak, daha derin ve anlamlı bir şekilde bilgiyi ölçmek.” (4S12)
}

ÖDBT beşinci sorusuna ait bulgulardan, öğretmen adaylarının alternatif ölçmedeğerlendirme yaklaşımları hakkındaki bilgi düzeylerinin istenilen seviyede olmadığı söylenebilir. Ayrıca öğretmen adayları ders planlarında ve ders anlatımlarında da alternatif ölçme-değerlendirme yaklaşımlarına yer vermemişlerdir. Sadece 4S34 öğretmen adayı öğrencilerin ön bilgilerini belirlerken zihin haritasından yararlanmıştır. 
Şekil 5. 3S41 Öğretmen Adayının Ders Planının Ölçme Kısmı

Jiçme değerlendirme

\author{
1. ${ }^{2}$ ilişkisine ait sayı dizisinin ilk 10 elemanım bulup ilişki \\ tablosunu çizin. Küp şekerlerle bu sayı dizisini modelleyin. \\ 2.Sizde bir kural belirleyip bu kuralın sayı dizisini oluşturun ve \\ istediğiniz elemanlarını kuralı kullanarak bulun.
}

3S41 öğretmen adayı dersin sonunda öğrencilerin konuyu anlayıp anlamadıklarını belirlemek amacıyla sadece iki açık uçlu soruya yer vermiştir.

ÖDBT altıncı sorusuna dördüncü sınıf öğretmen adaylarının 7'si (\%15.9), üçüncü sınıf öğretmen adaylarının 2'si (\%4.5), ikinci sınıf öğretmen adaylarının ise sadece 1'i (\%2.3) tam doğru cevap verirken birinci sınıf öğretmen adaylarının ise hiçbiri tam doğru cevap verememiştir. Bu soruda öğretmen adaylarının cevaplarının genel olarak kısmen doğru ifadeler içerdiği söylenebilir. Bir başka ifadeyle, öğretmen adaylarının verilen durumlarda hangi ölçme araçlarının kullanılabileceğini ifade etmekte zorlandıkları görülmüştür. Bu bağlamda 1S38 öğretmen adayı ile yapılan mülakata yer verilmiştir.

Şekil 6. 1S38 Öğretmen Adayının Altıncı Soruya Verdiği Cevap

6) Aşağıda verilen durumlarda hangi ollçme aracın tercih edersiniz?

\begin{tabular}{|c|c|}
\hline Durum & Olsme Araca \\
\hline $\begin{array}{l}\text { Ogrencilerin cebir ile ilgili bir kavram hakkındaki } \\
\text { görlląlerini detaylı bir şekilde ogrenmek için }\end{array}$ & 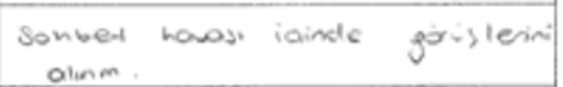 \\
\hline $\begin{array}{l}\text { Ogrencilerin cebir ile ilgili kavramlar arasında } \\
\text { nasıl bir ilişki kurduklarnn bg్grenmek için }\end{array}$ & Tanimiar isterm \\
\hline \multicolumn{2}{|l|}{$\begin{array}{l}\text { Kapsam geçerligi yoksek, okumasa kolay bir } \\
\text { olçme aracı }\end{array}$} \\
\hline $\begin{array}{l}\text { Cebir ile ilgili arasturma ve aron ortaya koyabilme } \\
\text { becerilerini ortaya çıarmak için }\end{array}$ & Sorv yamolarin. \\
\hline
\end{tabular}

A: Cevabını açıklar mısın?

1S38: Bir öğrencinin görüşlerini detaylı bir şekilde öğrenmek için önce o konu hakkında ne biliyor, bir sohbet havası içinde bilgilerini yoklamaya çalışırım.

A: Bu ölçme aracının adı nedir?

1S38: Bilmiyorum.

A: Peki kavramlar arasındaki ilişkiyi anlamak için?

1S38: Kavramlar arasındaki ilişkiyi anlamak için tanımlar isterim. O iki farklı kavramı nasıl tanımladıklarını ve bunlar arasında nasıl bir geçiş yapılabileceğini.

A: Kapsam geçerliği yüksek, okunması kolay bir ölçme aracı?

1S38: Onun hakkında fikrim yok.

A: Araştırma ve ürün ortaya koyma becerisini nasıl ölçersin?

1S38: Problem yazma şeklinde bir şeyler isteyebilirim. Bir ürün ortaya koyabilmeleri için becerilerini ortaya çıarabilmeleri için.

1S38 öğretmen adayının, verilen durumlarda hangi ölçme aracının kullanılabileceği hakkında yanlış bilgilere sahip olduğu görülmektedir. Aslında öğretmen adayı öğrencilerin cebirle ilgili bir kavram hakkında detaylı görüşlerini hangi ölçme aracıyla alacaklarının sorulduğu duruma "bir sohbet havası içinde bilgilerini 
yoklamaya çalışırım." şeklinde cevap verirken, bu ifadeyi herhangi bir ölçme aracının bir parçası olarak ifade edememesi bunun en açık örneğidir.

ÖDBT yedinci sorusuna hiçbir öğretmen adayı tam doğru cevap verememiştir. ÖDBT yedinci sorusuna dördüncü sınıf öğretmen adaylarının sadece 1'i (\%2.3) kısmen doğru (a) kategorisinde cevap vermiştir. Ayrıca birinci sınıf öğretmen adaylarının cevapları yanlış ve boş kategorilerinde yoğunlaşırken ikinci, üçüncü ve dördüncü sınıf öğretmen adaylarının cevaplarının ise kısmen doğru (b) ve yanlış kategorilerinde yoğunlaştığı görülmektedir. Bundan dolayı, öğretmen adayları ölçme araçlarının geçerlik ve güvenirliklerinin nasıl sağlanacağına dair bilgi düzeylerinin yetersiz olduğu söylenebilir. Çünkü öğretmen adayları vermiş oldukları cevaplarda geçerlik için uzman görüşü ve belirtke tablosundan, güvenirlik belirlemek için de cronbach alfa, KR-20, KR-21 ve puanlama güvenirliği gibi güvenirlik belirleme yöntemlerinden bahsetmemişlerdir. Ölçme araçlarının geçerliğini sağlamak için 3S23 "konu ile alakalı sorular hazırlarım", 2S37 ise "konu ile alakalı sorular sorulur" ifadelerini kullanmışlardır. Çalışmaya katılan öğretmen adayları genel olarak, belirtke tablosu, uzman görüşü ve literatür tarama gibi sıklıkla kullanılan geçerlik yöntemlerinden ise bahsetmemişlerdir. Ayrıca öğretmen adaylarının güvenirlik belirlenmesinde cronbach alfa, KR-20, KR-21 ve puanlama güvenirliği gibi güvenirlik belirleme yöntemleri arasında yer vermedikleri görülmüştür. Öğretmen adayları 2S37'ün "Kopya çekmelerini engellerim" ve 4S18' in "Rasgele hatalardan kaçınılmalıdır." ifadelerine benzer açıklamalar kullanmışlardır.

ÖDBT sekizinci sorusuna dördüncü sınıf öğretmen adaylarının sadece 1'i (\%2.3) tam doğru cevap vermiştir. Ayrıca dördüncü sınıf öğretmen adaylarının 8'i (\%18.2), üçüncü sınıf öğretmen adaylarının 1'i (\%2.3) kısmen doğru (a) kategorisinde cevap verirken, birinci ve ikinci sınıf öğretmen adaylarının ise hiç biri kısmen doğru (a) kategorisinde cevap verememiştir. Bu bağlamda, öğretmen adaylarının madde güçlüğü ve madde ayırt ediciliği kavramları hakkında yeterli düzeyde bilgi sahibi olmadıkları söylenebilir. Bazı öğretmen adaylarının madde güçlüğü veya madde ayırt ediciliklerini açıklayabildikleri fakat bunların nasıl hesaplanacağını bilmedikleri görülmektedir. 4S2 öğretmen adayı ile yapılan mülakatta, madde ayırt edicilik ve güçlük indekslerinin nasıl hesaplanılacağının sorulması üzerine öğretmen adayının bilmediğini ifade etmesi bu sonucu desteklemektedir.

A: Madde güçlüğünü açıklar mısın?

4S2: Eğer zorular çok zor hazırlanırsa sınıf ortamında derecesi daha düşük öğrenciler olumsuz yönde etkilenir. Eğer çok kolay olursa, çok başarılı olan öğrenciler de sıkılabilir. Öğrenmede isteksizlik olabilir. Bu nedenle sorular ne çok zor olmalı ne de çok kolay olmalı.

A: Hangi düzeyde olmalı?

4S2: Orta düzeyde olmalı her öğrencinin cevaplayacağı şekilde olmalı.

A: Madde güçlük indeksi kaç olmalıdır?

4S2: 0.50 olabilir mesela.

A: Madde güçlük indeksi nasıl hesaplanır?

4S2: Bilmiyorum.

A: Peki ayırt edicilik nedir?

4S2: Sorular net ve açık olmalı. Hoca sorudan ne istediğini açık bir şekilde belirtmeli ki öğrenci anlasın. Birde tek bir kazanımı ölçmeli, birden fazla bilgiyi istememeli.

A: Peki nasıl hesaplanır? 
4S2: Bilmiyorum.

ÖDBT dokuzuncu sorusuna dördüncü sınıf öğretmen adaylarının 4'ü (\%9.1), üçüncü sınıf öğretmen adaylarının 1'i (\%2.3) tam doğru cevap verirken birinci ve ikinci sınıf öğretmen adaylarının hiçbiri tam doğru cevap verememiştir. Bu soruda öğretmen adaylarının ölçme-değerlendirmenin amaçları hakkında kısmen doğru ifadeler kullandıkları söylenebilir. ÖDBT dokuzuncu sorusuna ait bulgulardan, öğretmen adaylarının eğitimde ölçme-değerlendirmenin temel amaçlarını ifade etmede zorlandıkları söylenebilir. Ayrıca öğretmen adayları eğitimde ölçme-değerlendirmenin temel amaçlarını ifade ederken bilişsel özelliklere odaklandıkları duyuşsal ve devinişsel özelliklere yönelik herhangi bir amaç ifade etmedikleri görülmektedir. Bu bağlamda, 1S29 ve 3S20 öğretmen adaylarının bilgi testine vermiş oldukları cevaplar ve 2S43 öğretmen adayı ile yapılan mülakata yer verilmiştir.

“Öğrenciye verilen bilgilerin öğrenci tarafından anlaşılıp anlaşılmadığını ölçmek için. (1S29) Anlatılan konunun ne kadar anlaşılıp anlaşılmadığını ve kavram yanılgılarını belirlemek için kullanılır." (3S20)

Şekil 7. 2S43 Öğretmen Adayının ÖDBT 9. Sorusuna Verdiği Cevap

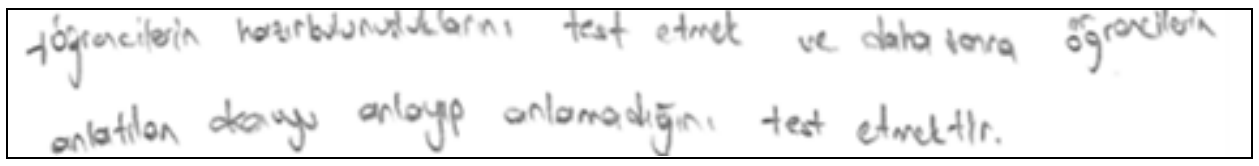

A: Cevabını açıklar mısın?

2S43: Öğrenciye verdiğimiz bilginin ne kadar anlayıp anlamadığını test etmektir. Öğrencinin hazır bulunuşluk durumunu test etmek de aynı şekilde önceden bilip bilmediklerini, bazı konular birbiriyle bağlantılı olduğu için onları test etmek için.

A: Ölçme-değerlendirmeyi sadece bilgi ölçmek için mi yaparız?

2S43: Verdiğimiz bilgiler için kullanırız.

A: Eğitimde öğrencinin hangi özelliklerini ölçeriz?

2S43: Bulundukları seviyeleri, bilgi konumlarını, bilgi düzeylerini ölçmeye çalışırız. Derste gösterdiğimiz verdiğimiz bilgilerin onlara ne kadar ulaşıp ulaşmadığını ölçmeye çalışırız.

A: Eğitimde ölçme-değerlendirmenin amacı sadece bilgi düzeyini ölçmek midir?

2S43: Benim bildiğim kadarıyla öyle.

ÖDBT onuncu sorusuna dördüncü sınıf öğretmen adaylarının 16's1 (\%36.4), üçüncü sınıf öğretmen adaylarının 3'ü (\%6.8) tam doğru cevap verirken birinci ve ikinci sınıf öğretmen adaylarının hiçbiri tam doğru cevap verememiştir. Bu soruda öğretmen adaylarının cevaplarının genel olarak kısmen doğru ifadeler içerdiği söylenebilir. Birinci ve ikinci sınıf öğretmen adayları eğitimde ölçme-değerlendirmenin sadece süreç sonunda konunun anlaşılıp anlaşılmadığını anlamak için yapıldığına vurgu yapmışlardır. 1S15 öğretmen adayının "Son aşamasında konuyu anlayıp anlamadığını ölçmek amacıyla gerçekleştirilir." ve 2S12 öğretmen adayının "Süreç sonunda gerçekleştirilir. Amacı, konunun anlaşılıp anlaşılmadığını anlama." açıklamaları örnek olarak gösterilebilir. Üçüncü sınıf öğretmen adayları ise eğitimde ölçme-değerlendirmenin sürecin hem başında hem de sonunda yapıldığını ifade etmişlerdir. Örneğin, 3S27 "Konuyu ilk vermeden konu hakkında ne derece bilgiye sahipler diye. Bir de dersin sonunda konuyu ne kadar anladılar diye yapılır." ifadesini kullanmıştır. Dördüncü sınıf öğretmen adayları diğer grupların aksine eğitimde ölçme- değerlendirmenin sürecin her aşamasında yapılması gerektiğini ifade ettikleri görülmektedir. Bu bağlamda 4S38 öğretmen adayının cevabı aşağıda verilmiştir. 
"Sürecin başında tanımaya yönelik test yaparız. Öğrencinin hazır bulunuşluğunu ölçmüş oluruz. Konuyu nasıl nerden başladığımızı biliriz. Süreç sırasında (formatif), öğrencilerin eksikliklerine anında dönüt vermek için yaparız. Tam öğrenmenin gerçekleşmesi önemlidir. Süreç sonunda (summatif) ise konuyu ne kadar anlamış, bu konu öğrencilere ne katmıştır, sorularına cevap ararız."

Aşağıda yer alan Tablo 6' da öğretmen adaylarının Ölçme-Değerlendirme Bilgi Testi'nden almış oldukları toplam puanlara ait betimsel istatistikler yer almaktadır.

Tablo 6

Ölçme-Değerlendirme Bilgi Testine Ait Betimsel İstatistikler

\begin{tabular}{ccccccc}
\hline & $\mathrm{N}$ & $\overline{\mathrm{X}}$ & Standart Sapma & Standart Hata & Min. & Max. \\
\hline 1. Sinif & 44 & 10,86 & 2.930 & .442 & 6 & 18 \\
2. Sinif & 44 & 15,66 & 3.169 & .478 & 7 & 20 \\
3. Sinıf & 44 & 19,66 & 2.736 & .412 & 14 & 25 \\
4. Sinif & 44 & 23,68 & 3.138 & .473 & 17 & 30 \\
Toplam & 176 & 17.47 & 5.616 & .423 & 6 & 30 \\
\hline
\end{tabular}

Tablo 6' da öğretmen adaylarının ÖDBT' den elde ettikleri toplam puan ortalamaları incelendiğinde, öğretmen adaylarının ölçme-değerlendirme bilgi puanlarının sınıf seviyesiyle doğru orantılı olarak arttığı görülmektedir. Diğer bir ifadeyle, en yüksek ÖDBT ortalaması dördüncü sınıf öğretmen adaylarına ait iken en düşük ortalama ise birinci sınıfta öğrenim gören öğretmen adaylarına aittir. Tablo 6'dan görüldüğü üzere 1. sınıfta 10.86 olan ÖDBT ortalaması 4. sınıfta 23.68 ' e ulaşmıştır. Buna karşın maksimum 40 puanın alınabildiği ÖDBT'de dördüncü sınıf öğretmen adaylarının ortalamalarının 23.68 olması, lisans eğitimi sonunda öğretmen adaylarının ölçme-değerlendirme bilgilerinin istenilen bir düzeye ulaşamadığının bir göstergesidir. Çünkü dördüncü sınıf öğretmen adayları ÖDBT'de yaklaşık olarak \%60'lık bir performans ortaya koymuşlardır.

Tablo 6' da yer alan verilerinden yararlanarak, öğretmen adaylarının ölçmedeğerlendirme bilgi düzeylerinde lisans eğitimleri boyunca her sınıf seviyesinde gelişme meydana geldiği söylenebilir. Fakat bu veriler, gruplar arasında istatistiksel olarak anlamlı bir fark olup olmadığını anlamak için yeterli değildir. Sınıf düzeyleri arasında anlamlı farklılık olup olmadığını anlamak için tek yönlü varyans analizi (ANOVA) kullanılmıştır.

Tablo 7

Ölçme-Değerlendirme Bilgi Testine Ait Puanların Anova Sonuçları

\begin{tabular}{cccccc}
\hline $\begin{array}{c}\text { Varyansın } \\
\text { Kaynağ }\end{array}$ & Kareler Toplamı & Serbestlik Derecesi & $\begin{array}{c}\text { Kareler } \\
\text { Ortalaması }\end{array}$ & F & $p$ \\
\hline Gruplararası & 3973.295 & 3 & 1324.432 & & \\
Gruplar içi & 1546.500 & 172 & 8.991 & 147.302 & .000 \\
Toplam & 5519.795 & 175 & & & \\
\hline
\end{tabular}


Tablo 7'de yer alan değerlere göre, örneklemde yer alan öğretmen adaylarının ölçme-değerlendirme bilgi testi puanlarında istatistiksel olarak anlamlı bir farklılık olduğu tespit edilmiştir $\left[\mathrm{F}_{(3,172)}=147.302, p<.05\right]$. Bu farklılığın hangi gruplar arasında olduğunun anlaşılması için hangi Posthoc testinin kullanılacağına karar vermeden önce varyansların homojenliğin incelenmesi gerekmektedir. Aşağıda yer alan Tablo 8'den görüldüğü üzere varyanslar homojen dağılmıştır $(p>0.05)$. Varyanslar homojen dağıldığı için PostHoc testlerinden Tukey testi kullanılmıştır.

Tablo 8

Ölçme-Değerlendirme Bilgi Testi Varyansların Homojenliğine Ait Sonuçlar

\begin{tabular}{cccc}
\hline Levene İstatistiği & Serbestlik Derecesi 1 & Serbestlik Derecesi 2 & $p$ \\
\hline .172 & 3 & 172 & .915 \\
\hline
\end{tabular}

Aşağıda yer alan Tablo 9'da gruplar (sınıf düzeyi) arasında farklılığın kaynağını belirlemek amaciyla kullanılan Tukey testine ait bulgular yer almaktadır.

Tablo 9

Ölçme-Değerlendirme Bilgi Testine Yönelik Tukey Testine Ait Bulgular

\begin{tabular}{|c|c|c|c|c|}
\hline $\begin{array}{c}\text { (I) } \\
\text { Sinıf }\end{array}$ & (J) Sinif & Ortalamalar Farkı (I-J) & Standart Hata & Sig. \\
\hline \multirow{3}{*}{ 1. Sinıf } & 2. Sinif & $-4.795^{*}$ & 639 & .000 \\
\hline & 3. Sinif & $-8.795^{*}$ & 639 & .000 \\
\hline & 4. Sinif & $-1 ., 818^{*}$ & .639 & .000 \\
\hline \multirow{3}{*}{ 2. Sinif } & 1. Sinif & $4.795^{*}$ & .639 & .000 \\
\hline & 3. Sinif & $-4.000^{*}$ & 639 & .000 \\
\hline & 4. Sinif & $-8.023^{*}$ & 639 & .000 \\
\hline \multirow{3}{*}{ 3. Sinıf } & 1. Sinif & $8.795^{*}$ & .639 & .000 \\
\hline & 2. Sinif & $4.000^{*}$ & .639 & .000 \\
\hline & 4. Sinıf & $-4.023^{*}$ & 639 & .000 \\
\hline \multirow{3}{*}{ 4. Sinıf } & 1. Sinif & $12.818^{*}$ & .639 & .000 \\
\hline & 2. Sinif & $8.023^{*}$ & .639 & .000 \\
\hline & 3. Sinıf & $4.023^{*}$ & .639 & .000 \\
\hline
\end{tabular}

* İstatistiksel olarak anlamlık düzeyi $p=0.05$ esas alınmıştır.

Tablo 9'da yer alan bulgular incelendiğinde sınıf düzeyine göre öğretmen adaylarının ölçme-değerlendirme bilgi testi puanlarının anlamlı bir şekilde farklılaştığ 1 görülmektedir. Diğer bir ifadeyle, sınıf düzeyi arttıkça öğretmen adaylarının ölçmedeğerlendirme bilgi puanları da artmaktadır. Özetle, öğretmen adaylarının ölçmedeğerlendirme bilgilerinin istatistiksel olarak anlamlı bir şekilde geliştiği fakat bu gelişmenin yeterli olmadığ 


\section{Sonuç ve Tartışma}

$\mathrm{Bu}$ çalışmada, ilköğretim matematik öğretmeni adaylarının pedagojik alan bilgisinin bileşenlerinden biri olan ölçme-değerlendirme bilgi düzeylerinin lisans eğitimleri boyunca nasıl bir gelişim gösterdiğinin belirlenmesi amaçlanmıştır. Çalışma sonunda, öğretmen adaylarının ölçme-değerlendirme bilgilerinin yetersiz olduğu ortaya konmuştur. Diğer bir ifadeyle, öğretmen adayları ölçme-değerlendirmenin amaçları, sürecin hangi aşamalarında niçin uygulanması gerektiği, madde güçlüğü ve ayırt ediciliği, öğrencilerin ön bilgilerini, kavram yanılgılarını, konuyu öğrenme düzeylerini belirlemek için hangi ölçme araçlarına kullanabileceklerine ilişkin yeterli bilgiye sahip olmadıkları söylenebilir. Benzer şekilde ilgili literatürde yer alan çalışmalarda, öğretmen ve öğretmen adaylarının ölçme-değerlendirmenin birçok boyutunda yeterli bilgi ve donanıma sahip olmadıkları sonucu ortaya konmuştur (Atılgan, Kan, \& Doğan, 2009; Aykutlu \& Şen, 2012; Baştürk \& Dönmez, 2011; Benzer \& Eldem, 2013; Birgin \& Gürbüz, 2008; Cizek, Fitzgerald, \& Rachor, 1996; Çıldır \& Şen, 2006; Daniel \& King, 1998; Gelbal \& Kelecioğlu, 2007; Gökkurt, 2014; Mede \& Atay, 2017; Özenç, 2013; Yazıcı \& Sözbilir, 2014; Yeşilyurt, 2012).

Öğretmenler ve öğretmen adayları kendilerini daha çok geleneksel ölçmedeğerlendirme yöntemlerini kullanmada yeterli hissetmekte buna karşın alternatif ölçme-değerlendirme yöntemlerini ise kullanmakta zorlanmaktadırlar (Baştürk \& Dönmez, 2011; Gelbal \& Kelecioğlu, 2007; Yazıcı \& Sözbilir, 2014). Bu bağlamda öğretmen ve öğretmen adayları öğrencilerin başarısını ve performansını belirlemede daha çok yazılı yoklama, çoktan seçmeli test ve soru-cevap yöntemlerini tercih etmektedirler (Birgin \& Gürbüz, 2008). Çünkü öğretmen ve öğretmen adayları, alternatif değerlendirme yöntemleri konusunda yeterli bilgi ve donanıma sahip değildirler (Birgin \& Gürbüz, 2008; Gelbal \& Kelecioğlu, 2007; Gökkurt, 2014; Özenç, 2013; Yazıcı \& Sözbilir, 2014). Ayrıca öğretmen ve öğretmen adayları öğrencilerin daha çok bilişsel özelliklerini ölçmeye odaklanmakta buna karşın duyuşsal ve psikomotor becerilerinin ölçülmesini ise ihmal etmektedirler (Benzer \& Eldem, 2013). Bunlara ek olarak, öğretmenlerin ve öğretmen adayların madde güçlüğü ve madde ayırt ediciliği gibi basit istatistiksel işlemleri yapmakta zorlanmaktadırlar (Cizek, Fitzgerald, \& Rachor, 1996; Yeşilyurt, 2012). İlgili literatürde ortaya çıkan sonuçlar ve bu araştırmanın sonuçları öğretmen ve öğretmen adaylarının ölçme-değerlendirme bilgi düzeylerinin ölçme-değerlendirmenin birçok boyutunda sınırlı olduğunu ve alternatif ölçme-değerlendirme hakkında yeterince bilgiye sahip olmadıkları sonucunu ortaya koymaktadır. Peki öğretmen adaylarının ölçme-değerlendirme bilgi gelişimleri lisans eğitimleri boyunca nasıl bir gelişim göstermektedir?

Çalışma sonucunda, öğretmen adaylarının ölçme-değerlendirme bilgi düzeyleri lisans eğitimleri boyunca sınıf düzeyi ile doğru orantılı olarak gelişim göstermiştir $\left[\mathrm{F}_{(3,172)}=147.302, p<.05\right]$. Diğer bir ifadeyle, sınıf düzeyi arttıkça öğretmen adaylarının ölçme-değerlendirme bilgi puanları da artmaktadır. Öğretmen adaylarının ölçmedeğerlendirme bilgi düzeylerindeki, en belirgin gelişim birinci sınıftan ikinci sınıfa geçişte meydana gelmiştir. Daha sonraki yıllara ise ölçme-değerlendirme bilgisinin gelişimi çok az yavaşlayarak devam etmiştir. Çalışma sonunda özetle, eğitim fakültesinde verilen öğretmenlik eğitimi sonucu öğretmen adaylarının ölçmedeğerlendirme bilgilerinin istenilen düzeye ulaşamadığı söylenebilir. İlgili literatürde yer alan birçok çalışmada öğretmen ve öğretmen adaylarının ölçme-değerlendirme 
bilgilerinin, lisans eğitimleri sonunda istenilen düzeye ulaşmadığı ve geliştirilmesi gerektiği ifade edilmiştir (Ashraf \& Zolfaghari, 2018; Baştürk \& Dönmez, 2011; Erdemir, 2007; Gelbal \& Kelecioğlu, 2007). Bu çalışmaya paralel olarak, Ashraf ve Zolfaghari (2018) lisans eğitimi sonunda öğretmen adaylarının ölçme okuryazarlıklarının istenilen düzeye ulaşmadığını ve geliştirilmesi gerektiğini belirtmiştir. Gelbal ve Kelecioğlu (2007) öğretmenlerin ölçme tekniklerinin kullanımı ve hazırlanması konusunda eğitime ihtiyaçları olduğunu ifade etmiştir. Baştürk ve Dönmez (2011) benzer şekilde "Okul Deneyimi” ve "Öğretmenlik Uygulaması" gibi meslek deneyim kazandıran derslerin ölçme-değerlendirme bilgisi gelişimini sağlamada yetersiz kaldığını ifade etmiştir. Erdemir (2007) ise öğretmenlere yükseköğretim kurumlarındaki öğrenimleri sırasında verilen ölçme-değerlendirme derslerinin niteliklerinin artırılması ve ölçme-değerlendirme ile ilgili bilgilerin hem teorik hem de uygulamalı olarak daha kapsamlı bir şekilde verilmesi gerektiği ifade edilmiştir. Bu çalışmanın sonuçları ve ilgili literatürün tartışılması, lisans eğitiminin öğretmen adaylarının ölçme-değerlendirme bilgi gelişimlerini sağlamada yetersiz olduğu sonucunu ortaya koymaktadır.

\section{Öneriler}

- Lisans eğitimi boyunca verilen ölçme-değerlendirme derslerinin içeriği gözden geçirilmelidir. İçeriğin düzenlenmesinde, yenilenen öğretim programlarında yer alan öğrenci merkezli yaklaşımlar esas alınmalıdır.

- Öğretmen adaylarının birinci sınıftan itibaren ölçme-değerlendirme bilgisine yönelik hem teorik hem de uygulamaya yönelik bilgiler kazanmaları sağlanmalıdır.

- Öğretmen adaylarına ölçme aracı hazırlama ve değerlendirme yapabilme firsatları sunulmalıdir. 
Purpose and Significance: The knowledge of assessment is related to teacher's knowing the prior knowledge, learning levels, misconceptions and learning difficulties of students regarding a learning domain (Baki, 2012; Magnusson, Krajcik, \& Borko, 1999). In other words, the knowledge of assessment can be defined as the knowledge of a teacher of the aims of measurement-evaluation and its methods, their use, the development of new tools and analysing and assessing the data collected with these tools (Baştürk \& Dönmez, 2011). Namely, teachers with the high level of measurement and evaluation knowledge will be able to determine the mistakes and misconceptions of students and give them the necessary feedback. Furthermore, these teachers will help students to learn subjects better by determining their levels of prior knowledge, learning deficits, and knowledge levels realistically. In this context, the aim of this study is to examine the assessment knowledge development among the pedagogical content knowledge sub-components of prospective elementary school mathematics teachers. This study has investigated the assessment knowledge levels of prospective teachers in the context of the measurement-evaluation approaches that the renewed secondary school mathematics curriculum (2017a) takes as a basis.

Method: The explanatory-confirmatory research design, one of the mixed research designs, was used in this study to examine the assessment knowledge development among the pedagogical content knowledge sub-components of prospective. The participants of the study consist of 176 prospective teachers in total, 44 of them being first-grade, 44 second-grade, 44 third-grade, and 44 fourth-grade students studying at the department of elementary school mathematics education of a university in Turkey. The real names of the prospective teachers were not used within the framework of research ethics. In this context, the first-grade students who participated in the study were coded from $1 S 1$ to $1 S 44$, second-grade students were coded from $2 S 1$ to $2 S 44$, third-grade students were coded from $3 S 1$ to $3 S 44$ and fourth-grade students were coded from $4 S 1$ to $4 S 44$. In this study, the assessment knowledge test (AKT), interview, observation was used as data collection tools to examine the assessment knowledge development of prospective teachers. In this study, Assessment knowledge tests consist of a total of ten open-ended questions (APP-1). The scoring categories used in the studies of Kwong et al. (2007) and Şahin et al. (2014) were used in the analysis of the answers given to the assessment knowledge test by prospective teachers. In this context, the answers of prospective teachers were analysed according to the holistic scoring categories of fully correct, partially correct a, partially correct b, incorrect, and blank. In this study, the coding reliability percentage investigating the correlation between the scoring made by different scorers was used to ensure the reliability of the assessment knowledge test. The coding reliability percentage was found to be $98 \%$. According to the results of the Kolmogorov-Smirnov test, the One-Way Variance Analysis (ANOVA) test was used in the comparison of the score averages of the grades since the data of prospective teachers on the assessment knowledge test were distributed normally. In this study, PASW Statistics Data Editor packaged software was used in the evaluation of the quantitative findings obtained. The data on the classroom observations of prospective teachers were presented in the study as direct quotations in line with the observation forms. The interviews conducted with prospective teachers were also reported as direct quotations. 
Results: As a result of the study, the average score of first-grade prospective teachers in the Assesment Knowledge Test (AKT) is 10.86, the average score of second-grade prospective teachers is 15.66 , the average score of third-grade prospective teachers is 19.66, and the average score of fourth-grade prospective teachers is 23.68. Furthermore, the average of the fourth-grade prospective teachers is 23.68 in the AKT from which the maximum score of 44 can be obtained. Considering the fact that partially correct $\mathrm{A}$ and partially correct $\mathrm{B}$ answers are the most frequent among the answers given by the fourth-grade prospective teachers to the AKT, it can be said that the assessment knowledge of fourth-grade prospective teachers did not reach a very high level at the end of their undergraduate education because it was observed that fourth-grade prospective teachers had difficulty in finding the fully correct answer in many questions.

Discussion and Conclusions: Indeed, it was also observed in many studies in the literature that the level of knowledge of teachers and prospective teachers on measurement and evaluation was not at the required level (Baştürk \& Dönmez, 2011; Benzer \& Eldem, 2013; Cizek, Fitzgerald, \& Rachor, 1996; Çıldır \& Şen, 2006; Daniel \& King, 1998; Gökkurt, 2014; Özenç, 2013; Yazıcı \& Sözbilir, 2014). Moreover, prospective teachers preferred traditional measurement-evaluation approaches more in their lesson practices. At the same time, it was observed prospective teachers did not benefit sufficiently from alternative measurement-evaluation approaches.

As a result of the study, it was observed that while first and second-grade prospective teachers preferred to solve questions by writing them on the board in measurementevaluation activities, third and fourth-grade prospective teachers used activities, worksheets and concept maps in addition to these. It was observed that first and secondgrade prospective teachers mostly focused on the evaluation for placement in their lesson practices, while third and fourth-grade prospective teachers performed measurement and evaluation at each stage of the process.

Upon examining the AKT averages of prospective teachers, it is observed that the assessment knowledge test scores of prospective teachers vary by the grade level. In other words, assessment knowledge scores increase as the grade level increases. As can be seen from the averages of prospective teachers, the greatest development has occurred when passing from the first grade to the second grade. The development of assessment knowledge has continued in subsequent years. As a result of the study, it can be said that the assessment knowledge of prospective teachers has not reached the required level as a result of the teaching education given at the faculty of education. In a similar way, Baştürk and Dönmez (2011) have expressed that lessons providing professional experience such as "School Experience" and "Teaching Practice" fail to ensure the development of measurement-evaluation knowledge.

\section{Kaynakça}


Ashraf, H., \& Zolfaghari, S. (2018). EFL teachers' assessment literacy and their reflective teaching. International Journal of Instruction, 11(1), 425-436.

Atılgan, H., Kan, A., \& Doğan, N. (2009). Ĕ̆itimde ölçme ve değerlendirme (4. Bask1). Ankara: Anı Yayıncılık.

Aykutlu, I., \& Şen, A. İ. (2012). Üç aşamalı test, kavram haritası ve analoji kullanılarak lise öğrencilerinin elektrik akımı konusundaki kavram yanılgılarının belirlenmesi. Ĕgitim ve Bilim, 37(166), 275-288.

Baki, M. (2012). Sınıf öğretmeni adaylarının matematiği öğretme bilgilerinin gelişiminin incelenmesi: bir ders imecesi (lesson study) çalışması (Yayınlanmamış Doktora Tezi). Karadeniz Teknik Üniversitesi Eğitim Bilimleri Enstitüsü.

Baştürk, S., \& Dönmez, G. (2011). Matematik öğretmen adaylarının pedagojik alan bilgilerinin ölçme ve değerlendirme bilgisi bileşeni bağlamında incelenmesi. Ahi Evran Üniversitesi Eğitim Fakültesi Dergisi, 12 (3), 17, 37.

Baumert, J., Kunter, M., Blum, W., Brunner, M., Voss, T., Jordan, A., ... \& Tsai, Y. M. (2010). Teachers' mathematical knowledge, cognitive activation in the classroom and student progress. American Educational Research Journal, 47(1), 133-180.

Benzer, A., \& Eldem, E. (2013). Türkçe ve edebiyat öğretmenlerinin ölçme ve değerlendirme araçları hakkında bilgi düzeyleri. Kastamonu Eğitim Dergisi, 21(2), 649-664.

Birgin, O., \& Gürbüz, R. (2008). Sınıf öğretmeni adaylarının ölçme ve değerlendirme konusundaki bilgi düzeylerinin incelenmesi. Selçuk Üniversitesi Sosyal Bilimler Enstitüsü Dergisi, 20, 163-179.

Büyüköztürk, Ş., Kılıç-Çakmak, E., Akgün, Ö.E., Karadeniz, Ş., \& Demirel, F. (2011). Bilimsel araştırma yöntemleri (8.baskı). Ankara: Pegem Yayınları.

Cizek,G.J., Fitzgerald,S.M., \& Rachor, R. E. (1996). Teacher's assesment practies: preparation, isolation and kitchen sink. Educational Assesment, 3(2), 159-179.

Cochran, K.F., DeRuiter, J.A., \& King, R.A (1993). Pedagogical content knowing: an integrative model for teacher preparation. Journal of Teacher Education, 44(4), 263-272.

Creswell, J. W. (2011). Educational research: planning, conducting, and evaluating quantitative and qualitative research (4th Ed). Pearson Publications, Inc.

Çıldır, I., \& Şen, A. İ. (2006). Lise öğrencilerinin elektrik akımı konusundaki kavram yanılgılarının kavram haritalarıyla belirlenmesi. Hacettepe Üniversitesi Ĕ̈itim Fakültesi Dergisi, 30(30), 92-101.

Daniel., L. G., \& King, D. A. (1998). Knowledge and use of testing and measurment literac of elementary and secondary teachers. Journal of Educational Research, 91(6), 331-344.

Denscombe, M. (2010). The good research guide: for small-scale social research projects (4th Edition). Open University Press.

Erdemir, Z. A. (2007). İlköğretim ikinci kademe öğretmenlerinin ölçme değerlendirme tekniklerini etkin kullanabilme yeterliliklerinin araştırılması: Kahramanmaraş 
örneği (Yayınlanmamış Yüksek Lisans Tezi). Kahramanmaraş Sütçü İmam Üniversitesi, Kahramanmaraş.

Gelbal, S., \& Kelecioğlu, H. (2007). Öğretmenlerin ölçme ve değerlendirme yöntemleri hakkındaki yeterlik algıları ve karşılaştıkları sorunlar. Hacettepe Üniversitesi Ĕ̈itim Fakültesi Dergisi, 33(33).

Gökbulut, Y. (2010). Sınıf ögretmeni adaylarının geometrik cisimler konusundaki pedagojik alan bilgileri (Yayınlanmamış Doktora Tezi). Gazi Üniversitesi Eğitim Bilimleri Enstitüsü.

Gökkurt, B. (2014). Ortaokul matematik öğretmenlerinin geometrik cisimler konusuna ilişkin pedagojik alan bilgilerinin incelenmesi (Yayımlanmamış doktora tezi). Atatürk Üniversitesi Eğitim Bilimleri Enstitüsü, Erzurum.

Gökkurt, B., Şahin, Ö., \& Soylu, Y. (2016). Öğretmen adaylarının değişken kavramına yönelik pedagojik alan bilgilerinin öğrenci hataları bağlamında incelenmesi. Pamukkale Üniversitesi Eğitim Fakültesi Dergisi, 39, 17-31.

Grossman, P. L. (1990). The making of a teacher: Teacher knowledge and teacher education. Teachers College Press, Teachers College, Columbia University.

Hashweh, M. Z. (2005). Teacher pedagogical constructions: a reconfiguration of pedagogical content knowledge. Teachers and Teaching, 11(3), 273-292.

Jenkins, O. F. (2010). Developing teachers' knowledge of students as learners of mathematics through structured interviews. Journal of Mathematics Teacher Education, 13, 141-154.

Johnson, B., \& Christensen, L. (2004). Educational research: quantitative, qualitative, and mixed approaches (2nd Edition). Boston, Pearson Education, Inc.

Kleickmann, T., Richter, D., Kunter, M., Elsner, J., Besser, M., Krauss, S., \& Jürgen Baumert, J. (2013). Teachers' content knowledge and pedagogical content knowledge: the role of structural differences in teacher education. Journal of Teacher Education 64(1) 90-106.

Kwong, C.W., Joseph, Y.K.K., Eric, C. M., \& Khoh, L. T. S. (2007). Development of mathematics pedagogical content knowledge in student teachers. The Mathematics Educator, 10(2), 27-54.

Magnusson, S., Krajcik, J., \& Borko, H. (1999). Nature, sources, and development of PCK for science teaching (pp. 95-120). In J. Gess-Newsome \& N.G. Lederman (Eds.), Examining PCK: The construct and its implications for science education. Boston: Kluwer Academic Press.

Marks, R. (1990). Pedagogical content knowledge: from a mathematical case to a modified conception. Journal of Teacher Education, 41, 3-11.

Mcmillian, H. J. \& Schumacher, S. (2010). Research in education. Boston, USA: Pearson Education.

Milli Eğitim Bakanlığı (MEB) (2017a). Matematik dersi öğretim programi (1, 2, 3, 4, 5, 6, 7 ve 8. siniflar). Ankara.

Milli Eğitim Bakanlı̆̆ı (MEB) (2017b). Öğretmenlik mesleği genel yeterlikleri. Ankara: Millî Eğitim Basımevi.

Mede, E., \& Atay, D. (2017). English language teachers' assessment literacy: The Turkish context. Ankara Üniversitesi TÖMER Dil Dergisi, 168(1), 43-60. 
Özenç, M. (2013). Sınıf öğretmenlerinin alternatif ölçme ve değerlendirme bilgi düzeylerinin belirlenmesi. Dicle Üniversitesi Ziya Gökalp Ĕ̈itim Fakültesi Dergisi, 21, 157-178.

Park, S., \& Oliver, J. S. (2008). Revisiting the conceptualisation of pedagogical content knowledge (PCK): PCK as a conceptual tool to understand teachers as professionals. Research in Science Education, 38(3), 261-284.

Patton, M. Q. (1987). How to use qualitative methods in evaluation. London: Sage.

Shulman, L.S. (1987). Knowledge and teaching: foundation of the new reform. Harvard Educational Review, 57(1), 1-21.

Smith, D. C, \& Neale, D. C. (1989). The construction of subject matter knowledge inprimary science teaching. Teaching and Teacher Education, 5, 1-20.

Stephens, A. C. (2006). Equivalence and relational thinking: preservice elementary teachers' awareness of opportunities and misconceptions. Journal of Mathematics Teacher Education, 9, 249-278.

Şahin, Ö. Erdem, E., Başıüyük, K., Gökkurt, B. \& Soylu, Y. (2014). Ortaokul matematik öğretmenlerinin sayılarla ilgili pedagojik alan bilgilerinin gelişiminin incelenmesi. Türk Bilgisayar ve Matematik Ĕ̈itimi Dergisi, 5(3), 207-230.

Şahin, Ö., Gökkurt, B., \& Soylu, Y. (2016). Examining prospective mathematics teachers' pedagogical content knowledge on fractions in terms of students' mistakes, International Journal of Mathematical Education in Science and Technology, 97(4), 531-551.

Şahin, Ö. (2016). An examination of development of pedagogical content konowledge of middle school prospective mathematics teachers on algebra (Unpublished Doctoral Dissertation). Atatürk University, Erzurum.

Tamir, P. (1988). Subject matter and releated pedagogical knowledge in teacher education. Teaching and Teacher Education, 4(2), 99-110.

Tanışlı, D., \& Köse, N.Y. (2013). Pre-service mathematic teachers' knowledge of students about the algebraic concepts. Australian Journal of Teacher Education, $38(2), 1-18$.

Tünkler, V., \& Güven, C. (2018). Mikroöğretim uygulamasının öğretmen adaylarının tamamlayıcı ölçme-değerlendirme tekniklerine yönelik okuryazarlık düzeylerine etkisi. Hacettepe Üniversitesi Ĕgitim Fakültesi Dergisi. Advance online publication. doi: 10.16986/HUJE.2018043466

Yazıcı, F., \& Sözbilir, M. (2014). İlköğretim 6-8. sınıf öğretmenlerinin ölçmedeğerlendirme yöntemlerine ilişkin kullanım sıklıkları ve yeterlik düzeyleri: Erzurum örneklemi. Necatibey Eğitim Fakültesi Elektronik Fen ve Matematik Ĕ̈itimi Dergisi, 8(2), 164-196.

Yeşilyurt, E. (2012). Öğretmen adaylarının ölçme ve değerlendirme alanına ilişkin genel yeterlik algıları. Mustafa Kemal Üniversitesi Sosyal Bilimler Enstitüsü Dergisi, 9(17), 377-395.

Yıldırım, A., \& Şimşek, H. (2011). Sosyal bilimlerde nitel araştırma yöntemleri (8. baskı). Ankara: Seçkin Yayıncılık. 


\section{Ek 1. Ölçme-Değerlendirme Bilgi Testi}

1) Herhangi bir öğrencinin matematik ile ilgili bir kavramda kavram yanılgısına sahip olup olmadığını belirlemek istiyorsunuz. Öğrencinizin sahip olduğu kavram yanılgısını nasıl ortaya çıkarabilirsiniz? Hangi ölçme-değerlendirme yöntem ve tekniklerden yararlanırsınız?

2) Aşağıda verilen özellikleri ölçmek için hangi ölçme ve değerlendirme yöntemleri tercih edilir?

Özellik Ölçme Araçları

Bilişsel

Duyuşsal

Psiko-Motor

3) Ortaokul öğrencilerine Cebir konularını anlatacaksınız. Fakat öğrencilerinizin bu konu ile ilgili hazır bulunuşluk düzeylerinin hangi seviyede olduğunu bilmiyorsunuz. Öğrencilerinizin hazır bulunuşluk düzeylerini belirlemek için neler yaparsınız?

4) Bir öğrencinin anlattığınız bir dersi anlayıp anlamadığını anlamak için neler yaparsınız?

5) Alternatif ölçme ve değerlendirme araçları nelerdir? Bu ölçme ve değerlendirme araçlarının matematik dersinde kullanılmasının amacı nedir?

6) Aşağıda verilen durumlarda hangi ölçme aracını tercih edersiniz?

\begin{tabular}{l}
\hline Durum \\
\hline Öğrencilerin cebir ile ilgili bir kavram \\
hakkındaki görüş̧lerini detaylı bir şekilde \\
öğrenmek için \\
Öğrencilerin cebir ile ilgili kavramlar arasında \\
nasıl bir ilişki kurduklarını öğrenmek için \\
Kapsam geçerliği yüksek, okuması kolay bir \\
ölçme aracı \\
$\begin{array}{l}\text { Cebir ile ilgili araştırma ve ürün ortaya } \\
\text { koyabilme becerilerini ortaya çıarmak için }\end{array}$ \\
\hline
\end{tabular}

7) Öğrencilerinize uygulayacağınız aşağıdaki ölçme araçlarının geçerlik ve güvenirliğini sağlamak için neler yaparsinız?

Ölçme Aracı Geçerlik Güvenirlik

\section{Yazılı Sinav}

Çoktan Seçmeli Test

8) İyi bir ölçme aracında yer alan maddelerin, madde güçlüğü ve madde ayırt ediciliği nasıl olmalıdır?

9) Eğitimde yapılan ölçme-değerlendirme faaliyetlerinin temel amaçları nelerdir?

10) Eğitimde değerlendirme; sürecin hangi aşamalarında, hangi amaçlarla gerçekleştirilir? 


\section{Ek 2. Ölçme-Değerlendirme Bilgisi Gözlem Formu}

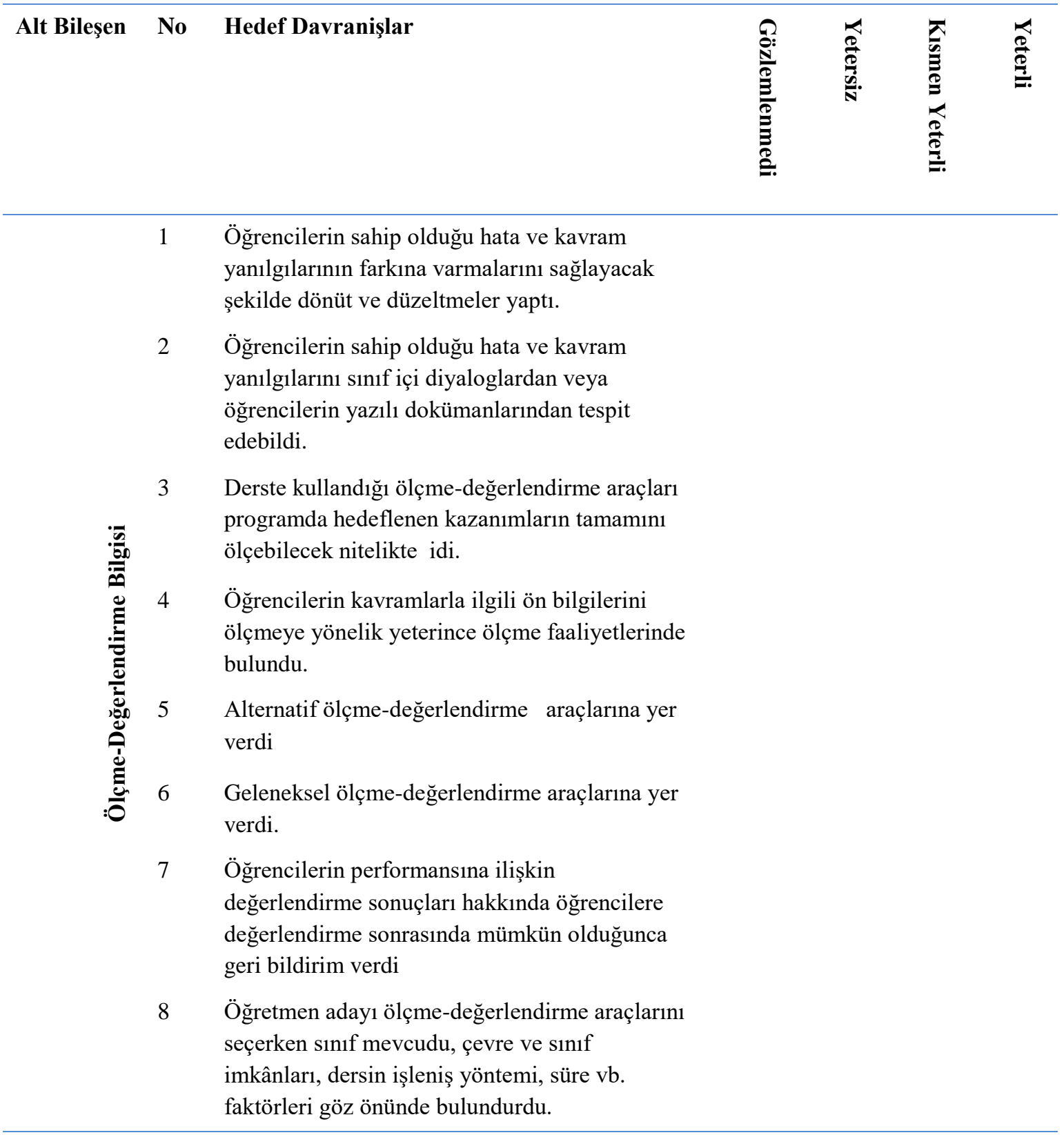


Ek 3. Ölçme-Değerlendirme Bilgi Testi Frekans-Yüzde Dağılımı

\begin{tabular}{llccccc}
\hline Soru & Puanlama & Tam & Kısmen & Kısmen & Yanlış & Boş \\
Numarası & Kategorisi & Doğru & Doğru a & Doğru b & &
\end{tabular}

\begin{tabular}{|c|c|c|c|c|c|c|c|c|c|c|c|}
\hline & Sınıf Düzeyi & $\mathbf{f}$ & $\%$ & $\mathbf{f}$ & $\%$ & $\mathbf{f}$ & $\%$ & f & $\%$ & f & $\%$ \\
\hline \multirow[t]{4}{*}{ Birinci Soru } & Birinci Sınıf ÖA & - & - & - & - & 24 & 54.5 & 7 & 15.9 & 13 & 29.5 \\
\hline & İkinci Sınıf ÖA & - & - & 4 & 9.1 & 33 & 75 & 3 & 6.8 & 4 & 9.1 \\
\hline & $\begin{array}{l}\text { Üçüncü Sınıf } \\
\text { ÖA }\end{array}$ & - & - & 16 & 36.4 & 27 & 61.4 & 1 & 2.3 & - & - \\
\hline & $\begin{array}{l}\text { Dördüncü Sınıf } \\
\text { ÖA }\end{array}$ & - & - & 19 & 43.2 & 24 & 54.5 & 1 & 2.3 & - & - \\
\hline
\end{tabular}

\begin{tabular}{llllllllllll}
\hline İkinci Soru & Birinci Sınıf ÖA & - & - & - & - & 7 & 15.9 & 11 & 25 & 26 & 59.1 \\
& İkinci Sınıf ÖA & - & - & 3 & 6.8 & 19 & 43.2 & 9 & 20.5 & 13 & 29.5 \\
& $\begin{array}{l}\text { Üçüncü Sınıf } \\
\text { ÖA }\end{array}$ \\
& - & - & 18 & 40.9 & 21 & 47.7 & 2 & 4.5 & 3 & 6.8 \\
& $\begin{array}{l}\text { Dördüncü Sınıf } \\
\text { ÖA }\end{array}$
\end{tabular}

\begin{tabular}{llllllllllll}
\hline Üçüncü Soru & Birinci Sınıf ÖA & - & - & 1 & 2.3 & 26 & 59.1 & 12 & 27.3 & 5 & 11.4 \\
& İkinci Sınıf ÖA & - & - & 4 & 9.1 & 34 & 77.3 & 5 & 11.4 & 1 & 2.3 \\
& $\begin{array}{l}\text { Üçüncü Sınıf } \\
\text { ÖA }\end{array}$ \\
& - & - & 6 & 13.6 & 36 & 81.8 & 2 & 4.5 & - & - \\
& $\begin{array}{l}\text { Dördüncü Sinıf } \\
\text { ÖA }\end{array}$
\end{tabular}

\begin{tabular}{|c|c|c|c|c|c|c|c|c|c|c|c|}
\hline \multirow{4}{*}{$\begin{array}{l}\text { Dördüncü } \\
\text { Soru }\end{array}$} & Birinci Sınıf ÖA & - & - & 3 & 6.8 & 38 & 86.4 & 3 & 6.8 & - & - \\
\hline & İkinci Sınıf ÖA & - & - & 7 & 15.9 & 37 & 84.1 & - & - & - & - \\
\hline & $\begin{array}{l}\text { Üçüncü Sınıf } \\
\text { ÖA }\end{array}$ & - & - & 12 & 27.3 & 29 & 65.9 & 3 & 6.8 & - & - \\
\hline & $\begin{array}{l}\text { Dördüncü Sınıf } \\
\text { ÖA }\end{array}$ & - & - & 16 & 36.4 & 28 & 63.6 & & & - & - \\
\hline
\end{tabular}

\begin{tabular}{|c|c|c|c|c|c|c|c|c|c|c|c|}
\hline \multirow[t]{4}{*}{ Beşinci Soru } & Birinci Sınıf ÖA & - & - & - & - & 4 & 9.1 & 25 & 56.8 & 15 & 34.1 \\
\hline & İkinci Sınıf ÖA & - & - & - & - & 3 & 6.8 & 31 & 70.5 & 10 & 22.7 \\
\hline & $\begin{array}{l}\text { Üçüncü Sınıf } \\
\text { ÖA }\end{array}$ & - & - & 6 & 13.6 & 14 & 31.8 & 21 & 47.7 & 3 & 6.8 \\
\hline & $\begin{array}{l}\text { Dördüncü Sınıf } \\
\text { ÖA }\end{array}$ & 2 & 4.5 & 23 & 52.3 & 12 & 27.3 & 7 & 15.9 & - & - \\
\hline
\end{tabular}

\begin{tabular}{llllllllllll}
\hline \multirow{2}{*}{ Altıncı Soru } & Birinci Sınıf ÖA & - & - & 2 & 4.5 & 15 & 34.1 & 8 & 18.2 & 19 & 43.2 \\
\cline { 1 - 3 }
\end{tabular}


$\begin{array}{lllllllllll}\text { İkinci Sınıf ÖA } & 1 & 2.3 & 8 & 18.2 & 26 & 59.1 & 5 & 11.4 & 4 & 9.1\end{array}$

$\begin{array}{lllllllllll} & \text { Üçüncü Sınıf } & 2 & 4.5 & 16 & 36.4 & 25 & 56.8 & - & - & 1\end{array}$

ÖA

$\begin{array}{llllllllll}\text { Dördüncü Sınıf } & 7 & 15.9 & 15 & 34.1 & 20 & 45.5 & 2 & 4.5 & -\end{array}$

ÖA

\begin{tabular}{llllllllllll}
\hline Yedinci Soru & Birinci Sınıf ÖA & - & - & - & - & 6 & 13.6 & 18 & 40.9 & 20 & 45.5 \\
& İkinci Sınıf ÖA & - & - & - & - & 19 & 43.2 & 18 & 40.9 & 7 & 15.9 \\
& Üçüncü Sınıf & - & - & - & - & 23 & 52.3 & 21 & 47.7 & - & - \\
& ÖA \\
& & & & & & & & & & \\
& $\begin{array}{l}\text { Dördüncü Sinıf } \\
\text { ÖA }\end{array}$
\end{tabular}

\begin{tabular}{llllllllllll}
\hline $\begin{array}{l}\text { Sekizinci } \\
\text { Soru }\end{array}$ & Birinci Sınıf ÖA & - & - & - & - & 1 & 2.3 & 10 & 22.7 & 33 & 75 \\
& İkinci Sınıf ÖA & - & - & - & - & 3 & 6.8 & 18 & 40.9 & 23 & 52.3 \\
& $\begin{array}{l}\text { Üçüncü Sınıf } \\
\text { ÖA }\end{array}$ \\
& - & - & 1 & 2.3 & 2 & 4.5 & 29 & 65.9 & 12 & 27.3 \\
& \\
& Dördüncü Sınıf \\
& ÖA
\end{tabular}

\begin{tabular}{|c|c|c|c|c|c|c|c|c|c|c|c|}
\hline \multirow{4}{*}{$\begin{array}{l}\text { Dokuzuncu } \\
\text { Soru }\end{array}$} & Birinci Sınıf ÖA & - & & - & - & 33 & 75 & 6 & 13.6 & 5 & 11.4 \\
\hline & İkinci Sınıf ÖA & - & - & 10 & 22.7 & 32 & 72.7 & 1 & 2.3 & 1 & 2.3 \\
\hline & $\begin{array}{l}\text { Üçüncü Sınıf } \\
\text { ÖA }\end{array}$ & 1 & 2.3 & 11 & 25 & 32 & 72.7 & - & - & - & - \\
\hline & $\begin{array}{l}\text { Dördüncü Sinıf } \\
\text { ÖA }\end{array}$ & 4 & 9.1 & 25 & 56.8 & 14 & 31.8 & 1 & 2.3 & - & - \\
\hline
\end{tabular}

\begin{tabular}{rlrlrllllllll}
\hline Onuncu Soru & Birinci Sınıf ÖA & - & - & - & - & 25 & 56.8 & 2 & 4.5 & 17 & 38.6 \\
& İkinci Sınıf ÖA & - & & 7 & 15.9 & 25 & 56.8 & 4 & 9.1 & 8 & 18.2 \\
& $\begin{array}{l}\text { Üçüncü Sınıf } \\
\text { ÖA }\end{array}$ \\
& 3 & 6.8 & 10 & 22.7 & 26 & 59.1 & 4 & 9.1 & 1 & 2.3 \\
& $\begin{array}{l}\text { Dördüncü Sınıf } \\
\text { ÖA }\end{array}$
\end{tabular}

This is an Open Access article distributed under the terms of the Creative CommonsAttribution-NonCommercial-ShareAlike 4.0 International (CC BY-NC-SA 4.0). For further information, you can refer to (C) $\bigcirc$ https://creativecommons.org/licenses/by-nc-sa/4.0/ 